\title{
Precambrian basin-margin fan deposits: Mesoproterozoic Bagalkot Group, India
}

Pradip K. Bose ${ }^{\mathrm{a}}$, Subir Sarkar ${ }^{\mathrm{a}}$, Soumik Mukhopadhyay ${ }^{\mathrm{a}}$, Bikas Saha ${ }^{\mathrm{a}}$ and Patrick Eriksson $^{\mathrm{b}}$

${ }^{a}$ Department of Geological Sciences, Jadavpur University, Kolkata 700032, India

${ }^{\mathrm{b}}$ Department of Geology, University of Pretoria, Pretoria 0002, South Africa

\section{Abstract}

Three-dimensional facies variability in coarse clastic sedimentary rocks (breccia, conglomerates and coarse-grained sandstones) at the base of the Ramdurg Formation suggests terrestrial scree and fans giving way downslope to fluvial sediments along the margin of the Mesoproterozoic Bagalkot basin in India. In consistency with the basic tenet of Precambrian alluvial sedimentation, fluvial architectural elements and field location-specific consistency in channel-flow direction support an invariably braided pattern for the rivers, although the architectural element-packaging pattern does show distinct changes downslope, with channel belts thinning and becoming more regular in their geometry. With possible persistence of a semi-arid climate, downslope change in flow durability in the channels was controlled primarily by water discharge, depending on position of the channels with respect to the mean level of the water table-basin-margin slope intersection.

Confined between an unconformity below and a granular lag succeeded by thoroughly wave-featured sandstone, and argillite-carbonate above, the coarse and poorly sorted clastic sedimentary rocks of the basal Ramdurg are interpreted as a base-level lowstand product, for which the sedimentation rate exceeded the rate of space creation for sediment accumulation. Consequently, the fan succession as a whole is coarsening-upward. Fluvial sections, nonetheless, fine upward as the depositional slope gradient became 
progressively reduced with aggradation of channels. Tectonics-related slope variation along and across the basin-margin, devoid of vegetation, dictated the sediment distribution and sequence building pattern primarily. Eventual termination of this basinmargin depositional system was caused by later enhancement in the rate of base-profile rise.

\section{Article Outline}

1. Introduction

2. Geological background

3. Facies

4. Facies architecture

4.1. Location 1, around Ramthal (Fig. 1 and Fig. 5)

4.1.1. Proximal section

4.1.2. Middle section

4.1.3. Distal section

4.1.4. Interpretation

4.2. Location II, Salgundi Hill (Fig. 1 and Fig. 6)

4.2.1. Proximal section

4.2.2. Middle section

4.2.3. Distal section

4.2.4. Interpretation

4.3. Location III, Bilgi Hill (Fig. 1 and Fig. 7)

4.3.1. Interpretation

5. Fluvial architectural elements and their packaging

6. Discussion

6.1. Basin-margin configuration

6.2. Bedrock composition vs. tectonic control

6.3. Control on flow duration

6.4. Base profile change

7. Conclusions

Acknowledgements

References 


\section{Introduction}

Basin-margin sedimentary cones are, more often than not, coarse-grained and bear special significance from a geological and economic point of view. Their lithology, facies spectrum and internal organization provide important clues for past tectonic and climatic settings, though source rock composition may also exert a significant influence. Basinmargin sedimentary cones often contain important economic placer deposits, notably of gold, diamonds, and uranium. Preferential occurrence of such cones at tectonically active margins makes them prone to fragmentation, transportation of the fragments to variable distances and even destruction. Their reconstruction is therefore often difficult and likely to be more so in older records.

Nonetheless, in the Precambrian, the general lack of vegetation on hill slopes could have engendered more such sedimentary cones, as these conditions readily induced slope failure, landslides as well as debris-flows. However, published reports are not that common, particularly for scree cone deposits, and alluvial fan deposits can easily be mistaken for coarse-grained braided fluvial deposits (e.g., Els, 1998) if palaeoslope data have not been collected (cf. Blair and McPherson, 1994). Channel systems within the Precambrian were predominantly braided ([Cotter, 1978], [Friend, 1978], [Long, 1978], [Fuller, 1985] and [Long, 2004]) due to lack of sediment-binding vegetation and due to poorly developed soils. The generally aggressive Precambrian palaeoweathering conditions, especially under the early greenhouse gas-dominated palaeo-atmosphere, provided more labile material (Donaldson and de Kemp, 1998) and this greater availability of fines would have promoted mass-flow and hyperconcentrated flow processes (Long, 2004), including possibly those in non-fan fluvial systems (Buck and Minter, 1985). Distinction of fan and fluvial systems with coarse-grained facies thus remains a challenge for Precambrian-aged deposits (e.g., Eriksson et al., 2006). Precambrian conditions further ensured more effective wind activity although preservation of aeolianites amidst frequently avulsing river channels may, however, have required some specific optimum conditions (Tirsgaard and Øxnevad, 1998). 
In this context, good preservation of the whole range of terrestrial sedimentary cones scree cone, alluvial fan and fan-delta - at the base of the Mesoproterozoic Bagalkot Group, Karnataka, India, notwithstanding folding and metamorphism (Jayaprakash et al., 1987), is indeed, fortuitous. Also fortuitous is the retention in these rocks of fine distinctions between deposits in rivers of varied longevity as well as local preservation of aeolian strata.

This paper seeks confirmation for the Precambrian alluvial sedimentation scenario, as envisaged above, in the Mesoproterozoic Ramdurg Formation at the base of the Bagalkot Group. The work has been done at three different locations, viz Ramthal, Salgundi and Bilgi, where breccias, conglomerates and poorly sorted sandstones rest upon the basement rock - granite, BIF or mica schists (Fig. 1a). All three locations are in the eastern sector of the east-west elongated exposure area of the Bagalkot Group, covering its northern, eastern and southern fringes. The studied stratigraphic interval includes the basal Salgundi Conglomerate and the lower part of the Saundatti Quartzite (Fig. 1b), capped by thick wave-featured sandstone followed further upward by carbonates and argillites belonging to the upper part of the Saundatti Quartzite (Fig. 1b). After a brief account of the facies constituents of the studied stratigraphic interval, classified on the basis of their inferred genetic processes, the paper examines the palaeogeography of the facies in the three study locations separately. Location-specific and facies-specific palaeocurrent patterns outline the palaeodrainage pattern and in conjunction with facies distribution patterns, indicate the general palaeoslope direction. Regional variability in palaeocurrent direction remains ambiguous, as there is no way to negate the effect of multiple folding of the Group. The paper further considers the facies architectural pattern, the fluvial architectural elements and their packaging in channel-belts, in order to help constrain the spatial variation in sedimentation pattern and to assess its possible intrabasinal and extrabasinal controls. 


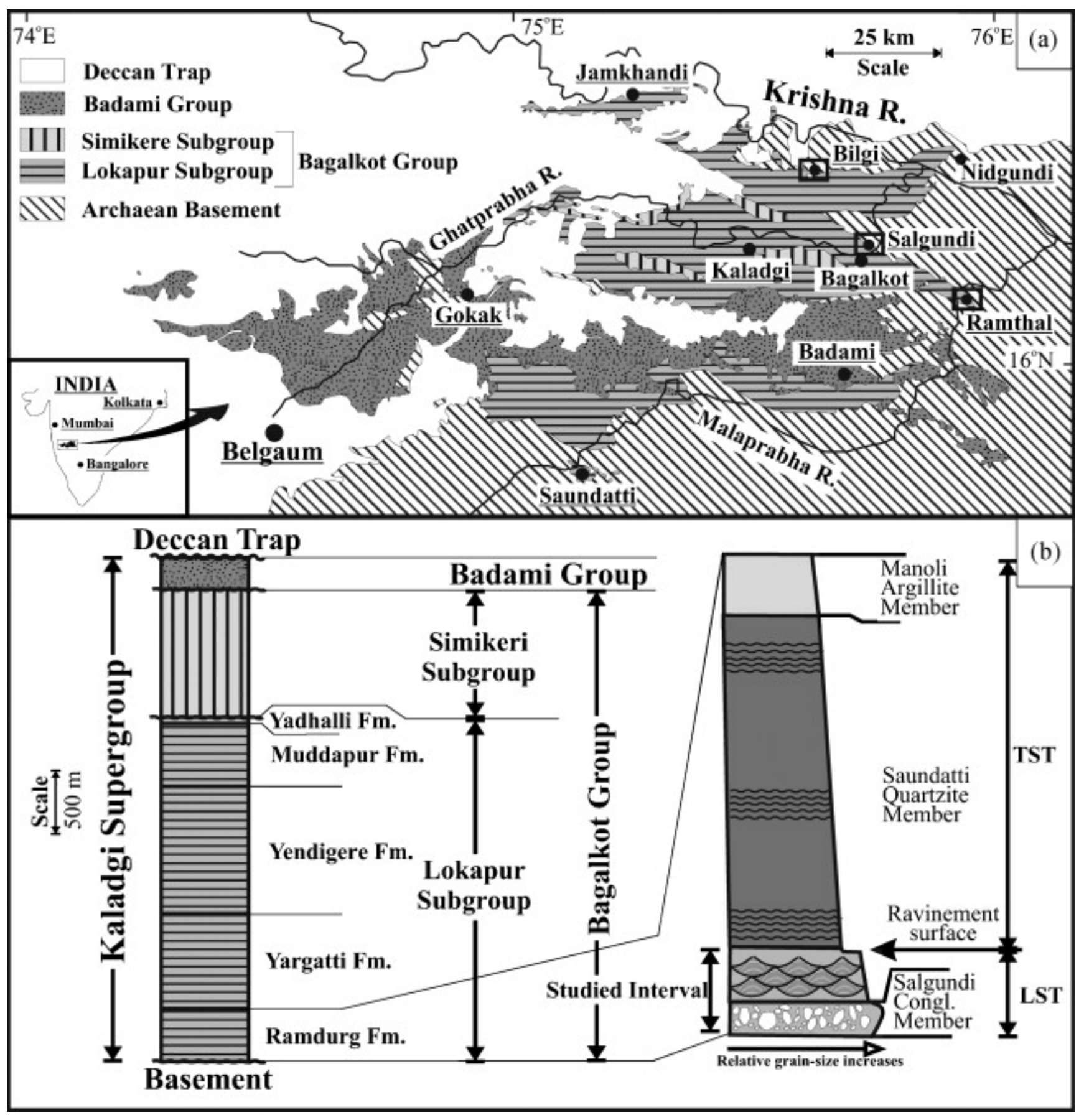

Fig. 1. (a) Outcrop distribution of rocks of the Kaladgi Supergroup, including the Bagalkot Group, India. Study locations are marked (squares) (modified after Jayaprakash et al., 1987). (b) Kaladgi Stratigraphy, highlighting its basal Ramdurg Formation (modified after Jayaprakash et al., 1987). Studied interval and sequence stratigraphic frame for the Ramdurg Formation are also indicated on the right. 


\section{Geological background}

The Bagalkot Group, forming the lower part of the Kaladgi Supergroup, is about $4250 \mathrm{~m}$ thick, well exposed around Bagalkot, Karnataka (Fig. 1a) and is dominated by siliciclastic rocks ([Viswanathaiah, 1977], [Jayaprakash et al., 1987], [Peshwa et al., 1989], [Kale, 1991] and [Kale et al., 1996]). The granitic basement rocks have been dated as 3.29-2.6 Ga on the basis of the Rb-Sr ratio using a $\left[{ }^{87} \mathrm{Sr} /{ }^{86} \mathrm{Sr}\right] \mathrm{vs} .\left[{ }^{87} \mathrm{Rb} /{ }^{87} \mathrm{Rb}\right]$ plot ([Jayaram et al., 1983] and [Rao et al., 1999]), while the Bagalkot Group has been assigned a Middle Riphean age on the basis of a stromatolite assemblage found at the mid-level of the Bagalkot Group ([Viswanathaiah and Gowda, 1975], [Raha and Sastry, 1982] and [Garuraja, 1983]). Subsequently Jayaprakash et al. (1987) reviewed the stromatolite assemblage to reconfirm its inferred age of ca.1260-1000 Ma.

The Bagalkot Group comprises two subgroups, lower Lokapur and upper Simikeri. The Lokapur Subgroup comprises five formations. The basal Ramdurg Formation, up to $475 \mathrm{~m}$ thick is overall fining-upward and is constituted by three Members, the Salgundi Conglomerate, Saundatti Quartzite and Manoli Argillite in ascending order (Fig. 1b). This paper focuses upon the Salgundi Conglomerate (up to $31 \mathrm{~m}$ thick) and the basal $40 \mathrm{~m}$ of the Saundatti Quartzite. Petrographically, the Salgundi Conglomerate is both oligomictic and polymictic. The Saundatti Quartzite comprises litharenites and arkoses within its basal segment, but becomes quartzarenitic in the upper levels.

The Bagalkot Group is interpreted by some to have been deposited within an intracratonic rift basin (Radhakrishna and Vaidyanathan, 1994) while others tacitly assume it to be largely marine ([Viswanathaiah, 1977], [Jayaprakash et al., 1987], [Peshwa et al., 1989] and [Kale et al., 1996]). The facies analysis carried out so far on the sedimentary rocks constituting the Kaladgi Supergroup was based solely on broad lithological categories like conglomerate, sandstone, shale and carbonate (Kale et al., 1996) and was thus too superficial to grasp the great variability in depositional mechanism and palaeogeography that underpinned development of the Bagalkot Group. In this study we make a more detailed, facies-based study of only the basal ruditic portion of the Group, up to $70 \mathrm{~m}$ in thickness. 


\section{Facies}

Facies constituents of the Salgundi Conglomerate Member and the studied basal segment of the Saundatti Quartzite Member, taking into account their lithology, sedimentary structures, body geometry, and facies associations, are described and interpreted in Table 1. The facies are basically process-related, but may have direct palaeoenvironmental and palaeogeographic import (Fig. 2, Fig. 3 and Fig. 4).

\section{Table 1.}

Facies constituents of the Salgundi Conglomerate and the basal part of the Saundatti Quartzite beneath the 10 s of meters of the entirely wave-featured marine or lacustrine segment

\begin{tabular}{|c|c|}
\hline Description & Interpretation \\
\hline $\begin{array}{l}\text { A }_{1} \text {. Clast-supported chaotic breccias, thick, } \\
\text { up to about } 2 \text { m, rapidly wedging away } \\
\text { from the basement exposure, generally } \\
\text { found at the bottom of the formation, } \\
\text { having base jagged as clasts frequently } \\
\text { penetrate into the substratum and clast } \\
\text { composition restricted to that of the } \\
\text { basement in immediate vicinity (Fig. } 2 \text { a } \\
\text { and b). }\end{array}$ & $\begin{array}{l}\text { Scree Breccia facies (Selley, 1965): } \\
\text { Penetration of clasts into the underlying } \\
\text { substrata indicates free-fall of clasts. The } \\
\text { facies resembles those described by Blair } \\
\text { and McPherson (1994) as rock avalanche } \\
\text { wedges. }\end{array}$ \\
\hline $\begin{array}{l}\text { A }_{2} \text { Matrix-supported conglomerate, clasts } \\
\text { having distinctly smaller size and less } \\
\text { angularity with respect to those in facies } \\
\text { A }_{1} \text {. Beds have planar bases, in contrast to } \\
\text { their tops rugged as clast protrude above } \\
\text { the bed surface and geometry lenticular, } \\
\text { with discernibly convex upward at places, } \\
\text { internally massive, up to } 80 \text { cm thick and } \\
8 \text { m long in exposures (Fig. } 2 \text { c). }\end{array}$ & $\begin{array}{l}\text { Debris-flow conglomerate facies (Blair and } \\
\text { McPherson, 1994): Chaotic orientation of } \\
\text { clasts and their protrusion above bed } \\
\text { surface indicate high matrix strength of the } \\
\text { parent flows. }\end{array}$ \\
\hline
\end{tabular}




\begin{tabular}{|c|c|}
\hline Description & Interpretation \\
\hline $\begin{array}{l}\mathrm{A}_{3} \text {. Distinctly poorer in matrix than } \mathrm{A}_{2} \text {, yet } \\
\text { matrix-supported, up to } 50 \mathrm{~cm} \text { thick, and } \\
\text { of maximum preserved outcrop length } \\
\text { about } 3 \mathrm{~m} \text {, devoid of grading, but its most } \\
\text { distinctive feature is bed-parallel or long } \\
\text { axis imbrication of elongated clasts (Fig. } \\
\text { 2d). Closely associated with } \mathrm{A}_{2} \text {, locally } \\
\text { grading laterally into it. }\end{array}$ & $\begin{array}{l}\text { Sheared mass-flow conglomerate facies } \\
\text { (Bose and Sarkar, 1991). Bed-parallel } \\
\text { orientation is a manifestation of flow- } \\
\text { internal shear; long axis imbrication of } \\
\text { clasts indicates settling through dispersion } \\
\text { (Walker, 1984). }\end{array}$ \\
\hline $\begin{array}{l}\text { A }_{4} \text {. Conglomerate broadly similar to that } \\
\text { of } A_{2} \text {, but possesses a relatively greater } \\
\text { clast concentration and reverse grading, } \\
\text { albeit feeble (Fig. } 2 \text { e). Associated with } A_{2} \text {, } \\
\text { but not as common in occurrence. }\end{array}$ & $\begin{array}{l}\text { Modified grain-flow conglomerate facies } \\
\text { (e.g., [Lowe, 1976], [Middleton and } \\
\text { Hampton, 1976], [Schultz, 1984], [Mack } \\
\text { and Rasmussen, 1984], [Nemec and } \\
\text { Postma, 1993], [Mulder and Alexander, } \\
\text { 2001], [Davis et al., 2002] and [Gani, } \\
\text { 2004]): Reverse grading manifests } \\
\text { dispersive pressure. }\end{array}$ \\
\hline $\begin{array}{l}\text { A }_{5} \text { Slightly convex upward conglomerate } \\
\text { beds, clast-supported at base, but } \\
\text { progressively enriched in sand upwards. } \\
\text { Locally bear crude cross-strata, especially } \\
\text { in its top sandy part. Outcrop length } \\
\text { generally less than } 6 \mathrm{~m} \text {, bed-thickness up } \\
\text { to } 70 \mathrm{~cm} \text { (Fig. } 2 \mathrm{f}) \text {. }\end{array}$ & $\begin{array}{l}\text { Sieve conglomerate facies (Todd, 1989). It } \\
\text { is thought to represent bedforms, which } \\
\text { were frozen because of rapid draining out } \\
\text { of water; sand infiltrated from above as the } \\
\text { flow waned. }\end{array}$ \\
\hline $\begin{array}{l}\text { A }_{6} \text {. Clast-supported sheet conglomerate } \\
\text { showing little lateral variability in } \\
\text { thickness }(\sim 80 \mathrm{~cm}) \text { within which clasts are } \\
\text { often bed-parallel or imbricated with their } \\
\text { intermediate axis (Fig. } 2 \mathrm{~g}) \text {. This facies } \\
\text { occurs in close association with } \mathrm{A}_{5} \text { and } \\
\text { locally with } \mathrm{A}_{2} \text {. }\end{array}$ & $\begin{array}{l}\text { Sheet flow conglomerate facies ([Hein, } \\
\text { 1982], [Fisher, 1971] and [Enos, 1977]). } \\
\text { Clast-supported nature in conjunction with } \\
\text { sheet-like bed geometry and intermediate } \\
\text { axis clast imbrication indicate deposition } \\
\text { from high energy tractive flow (Walker, } \\
\text { 1984). }\end{array}$ \\
\hline
\end{tabular}




\begin{tabular}{|c|c|}
\hline Description & Interpreta \\
\hline $\begin{array}{l}\text { A7. Thin (>5 cm) almost sheet-like } \\
\text { granular sandstone pinching on sides } \\
\text { (maximum measured outcrop length } \\
20 \mathrm{~cm} \text { ) with minor erosion at base; } \\
\text { internally massive, but may give way } \\
\text { upward gradationally to crudely defined } \\
\text { cross-strata followed by planar laminae } \\
\text { (Fig. } 2 \text { a). All conglomeratic facies together } \\
\text { make a preferred facies association that } \\
\text { locally incorporates sandy A }{ }_{7} \text { and B } \\
\text { (described below); in turn, isolated lenses } \\
\text { of } A_{2}, A_{5} \text { and } A_{6} \text { occur within facies B and } \\
\text { also in facies association C described } \\
\text { below. }\end{array}$ & $\begin{array}{l}\text { Hillwash sandstone facies: General } \\
\text { massiveness manifests rapid settling, } \\
\text { possibly from grainflow (Shanmugam, } \\
\text { 2000). Gradational upward transition from } \\
\text { massiveness to crude cross-strata apparently } \\
\text { manifests decreasing sediment saturation in } \\
\text { the flow, while the planar laminae at top of } \\
\text { beds indicates increase in flow shear with } \\
\text { rapid decrease in flow depth at the } \\
\text { penultimate stage of deposition. Deposition } \\
\text { possibly took place from minor water flows } \\
\text { arisen from occasional rain on steep } \\
\text { hillslope. }\end{array}$ \\
\hline $\begin{array}{l}\text { B. Granular/pebbly sandstone } \\
\text { characterized by juxtaposition of lenticular } \\
\text { channel-form bodies (Fig. } 2 \mathrm{~h} \text {; measured } \\
\text { width <12 m and thickness <90 cm) with } \\
\text { marked erosion at bottom, and internally } \\
\text { either massive or trough cross-stratified } \\
\text { but may be planar laminated at top (Fig. } \\
2 \mathrm{i} \text { ). This facies is volumetrically important } \\
\text { not only the Saundatti Quartzite, but also } \\
\text { of the Salgundi Conglomerate at places. In } \\
\text { close association with conglomerates it is } \\
\text { rich in pebbles (<2 cm in length), scattered } \\
\text { randomly within beds despite presence of } \\
\text { crude cross-strata (Fig. } 2 \text { j), but beyond that } \\
\text { pebbles, generally of smaller size, } \\
\text { concentrate along the channel bases (Fig. }\end{array}$ & $\begin{array}{l}\text { Streamlet granular sandstone facies: The } \\
\text { poorly sorted granular sandstone with } \\
\text { channel geometry is possibly of fluvial } \\
\text { origin. Crudely cross-stratified bodies with } \\
\text { randomly strewn pebbles suggest deposition } \\
\text { from high-velocity river flashflood } \\
\text { ([Pfluger and Seilacher, 1991] and [Blair } \\
\text { and McPherson, 1994]). }\end{array}$ \\
\hline
\end{tabular}




\begin{tabular}{|c|c|}
\hline Description & Interpretation \\
\hline $\begin{array}{l}\text { 2h). Pebbly sandstone bodies are often } \\
\text { intercalated with pebble-free coarse } \\
\text { sandstone. }\end{array}$ & \\
\hline $\begin{array}{l}\mathrm{C}_{1} \text {. Solitary set of scallop-based trough } \\
\text { cross-strata of average thickness } 80 \mathrm{~cm} \\
\text { passing downcurrent into down-dip cross- } \\
\text { strata in poorly sorted granular sandstone } \\
\text { (Fig. } 3 \text { a and b), pebbles concentrate along } \\
\text { the foreset bases; traced incompletely } \\
\text { though, up to } 120 \text { m in paleocurrent } \\
\text { direction and } 7.5 \text { m transverse to it, having } \\
\text { distinct convex upward geometry in the } \\
\text { latter direction (Fig. } 3 c \text { ). The down-dip } \\
\text { cross-strata are granule-free, less steep. } \\
\text { The smaller cross-strata dip in the same } \\
\text { direction as the larger ones and their sets } \\
\text { are about } 7 \text { cm (Fig. } 3 a) . \text { On instances, } \\
\text { immediately under surfaces that truncate } \\
\text { their tops, there are thin (<5 cm) patches of } \\
\text { crinkled adhesion laminae and inversely } \\
\text { graded translatent strata, traced laterally up } \\
\text { to } 2 \text { m (Fig. } 3 d \text { and e). }\end{array}$ & $\begin{array}{l}\text { Fluvial bar facies (a): The poorly sorted } \\
\text { facies revealing unimodal paleocurrent } \\
\text { direction (see next section) is possibly of } \\
\text { fluvial channel origin. Steeper foresets } \\
\text { laterally transiting into downdip cross-strata } \\
\text { manifests slackening of current. Aeolian } \\
\text { features like adhesion laminae and } \\
\text { translatent strata evince emergence of bars } \\
\text { above water surface, although remaining } \\
\text { within water capillary zone. }\end{array}$ \\
\hline $\begin{array}{l}\mathrm{C}_{2} \text {. Tabular cross-strata of set thickness } \\
20 \mathrm{~cm} \text { in granule-free, yet poorly sorted } \\
\text { sandstone. Where found in lateral contact } \\
\text { with } \mathrm{C}_{1} \text { they recline on the bar flank } \\
\text { having orientation almost at right angle to } \\
\text { that of attached } \mathrm{C}_{1} \text { cross-strata. This facies } \\
\text { could never be traced more than } 70 \mathrm{~cm} \text { in } \\
\text { dip direction of the cross-strata. }\end{array}$ & $\begin{array}{l}\text { Fluvial Bar-attached facies: This facies } \\
\text { presumably formed by sand avalanching } \\
\text { down the flank of the bars. Operation of a } \\
\text { secondary current at an angle to the bar } \\
\text { axes, possibly at low water stage when bar } \\
\text { configurations could influence the channel } \\
\text { flow direction, is suggested. }\end{array}$ \\
\hline
\end{tabular}




\begin{tabular}{|c|c|}
\hline Description & Interpretation \\
\hline $\begin{array}{l}\mathrm{C}_{3} \text {. Characterized by granular sediment, } \\
\text { internally characterized by laterally } \\
\text { discontinuous planar laminae and sheet- } \\
\text { like geometry, although eroded on sides. } \\
\text { Granule size matches with the coarsest } \\
\text { fraction of } \mathrm{C}_{1} \text { and } \mathrm{C}_{2} \text { combined on which it } \\
\text { overlies erosionally. Its maximum outcrop } \\
\text { length measured is about } 2 \mathrm{~m} \text { and } \\
\text { thickness } \ldots 5 \mathrm{~cm} \text {. }\end{array}$ & $\begin{array}{l}\text { Bar-top facies (1a): Formed apparently at } \\
\text { low water stage when bar top was reworked } \\
\text { by a strong flow, possibly during } \\
\text { emergence. Finer fraction of bar-top } \\
\text { sediment was winnowed out leaving the } \\
\text { granules as erosional lag. }\end{array}$ \\
\hline $\begin{array}{l}\mathrm{C}_{4} \text {. Characterized by trough cosets in } \\
\text { poorly sorted medium to fine-grained } \\
\text { sandstone of lenticular geometry with } \\
\text { concave upward base (Fig. 3f). The cosets } \\
\text { are, on average, } 30-35 \mathrm{~cm} \text { thick, while } \\
\text { their constituent sets are mostly around 8- } \\
9 \mathrm{~cm} \text {. The facies units are up to } 1.5 \text { m thick } \\
\text { and laterally traceable up to } 6 \text { m generally } \\
\text { terminating against } \mathrm{C}_{1} \text {, interrelationship } \\
\text { between the two facies being onlapping } \\
\text { and downlapping. Palaeocurrent direction } \\
\text { determined from this facies, more or less, } \\
\text { follows that derived from } \mathrm{C}_{1} \text { (see next } \\
\text { section). }\end{array}$ & $\begin{array}{l}\text { Fluvial Channel-floor Facies (a): This } \\
\text { poorly sorted sandstone in lateral } \\
\text { equivalence to inferred fluvial bars is } \\
\text { considered as channel-floor deposit formed } \\
\text { principally by dune migration. }\end{array}$ \\
\hline $\begin{array}{l}\mathrm{D}_{1} \text {. Like } \mathrm{C}_{1} \text { this facies is also characterized } \\
\text { by solitary sets of trough cross-strata } \\
\text { (thickness up to } 60 \mathrm{~cm} \text { ) traced } \\
\text { incompletely up to about } 100 \mathrm{~m} \text {, but the } \\
\text { sandstone is granule-free, medium to fine } \\
\text { grained and the foresets do not have } \\
\text { scalloped bases, although back-flow }\end{array}$ & $\begin{array}{l}\text { Fluvial Bar Facies (b): Like } \mathrm{C}_{1} \text {, this finer } \\
\text { grained facies is also attributed to migration } \\
\text { of bars, but at relatively downstream part, } \\
\text { under flow relatively weaker, but more } \\
\text { steady, both in terms of intensity and } \\
\text { direction; no evidence of secondary flow, } \\
\text { such as, bar-flank accretion deposit, like } \mathrm{C}_{2} \text {, }\end{array}$ \\
\hline
\end{tabular}




\begin{tabular}{|c|c|}
\hline Description & Interpretation \\
\hline $\begin{array}{l}\text { ripples and small cross-stratified scour-fills } \\
\text { locally occurs at top of them (Fig. } 4 \text { a). } \\
\text { Aeolian features, as those in } \mathrm{C}_{1} \text {, are also } \\
\text { conspicuous in absence. Cross-strata } \\
\text { orientation is area-wise highly consistent } \\
\text { (see next section). Maximum measured } \\
\text { outcrop length of this facies in the } \\
\text { direction of large cross-strata is about } \\
30 \mathrm{~m} \text {. }\end{array}$ & $\begin{array}{l}\text { was found associated. Only slight flow } \\
\text { unsteadiness is reflected in the bar-top } \\
\text { scours. Smaller height of the bars suggests } \\
\text { lower flow depth. }\end{array}$ \\
\hline $\begin{array}{l}D_{2} \text {. Broadly similar to } C_{3} \text { in appearance, } \\
\text { but finer grained even with respect to } D_{1} \\
\text { on which it invariably rests and its internal } \\
\text { planar laminae are well defined and } \\
\text { laterally persistent (Fig. 4b). Its thickness } \\
\text { is around } 10 \mathrm{~cm} \text { and maximum preserved } \\
\text { outcrop length } 2.5 \mathrm{~m} \text {. }\end{array}$ & $\begin{array}{l}\text { Bar-top facies (b): Like } \mathrm{C}_{3} \text {, this facies is } \\
\text { also interpreted as a product of reworking } \\
\text { of previously deposited bar-top sediments, } \\
\text { but selectively the finer fraction, } \\
\text { presumably during falling water stage, but } \\
\text { at relatively low shear, perhaps without or } \\
\text { before emergence of the bar (cf. [Cant, } \\
\text { 1978] and [Kirk, 1983]). }\end{array}$ \\
\hline $\begin{array}{l}\mathrm{D}_{3} \text {. Like } \mathrm{C}_{4} \text { this facies is also characterized } \\
\text { by trough cosets, differing only by finer } \\
\text { sand grain-size, shorter set and coset } \\
\text { thicknesses, up to } 6 \mathrm{~cm} \text { and } 20 \mathrm{~cm} \text {, } \\
\text { respectively. Laterally this facies is of } \\
\text { lenticular geometry, passing into } \mathrm{D}_{1} \text {. The } \\
\text { paleocurrent direction derived from it } \\
\text { roughly conforms that of the associated } \\
\text { large cross-strata. } \mathrm{D}_{1}, \mathrm{D}_{2} \text { and } \mathrm{D}_{3} \text { together } \\
\text { constitute a preferred association. }\end{array}$ & $\begin{array}{l}\text { Channel-floor facies (b): Like } \mathrm{C}_{4} \text { this facies } \\
\text { is also attributed to migration of smaller } \\
\text { dunes along river channel floor } \\
\text { accommodating possibly relatively } \\
\text { shallower water depth at more downstream } \\
\text { part. }\end{array}$ \\
\hline $\begin{array}{l}\text { E. This facies occurs only at top of the } \\
\text { studied stratigraphic segment, overlying }\end{array}$ & $\begin{array}{l}\text { Transitional facies: Because of alternations } \\
\text { between unidirectional traction-dominated }\end{array}$ \\
\hline
\end{tabular}




\begin{tabular}{|c|c|}
\hline Description & Interpretation \\
\hline $\begin{array}{l}\text { either facies B or facies association D and } \\
\text { is characterized frequently by wave } \\
\text { features, like wave ripples (Fig. 4c), wavy } \\
\text { laminae, quasi-planar strata, hummocky } \\
\text { cross-strata, chevron cross-strata and } \\
\text { occasional off-shoots in well sorted fine } \\
\text { grained sandstone. These beds are, } \\
\text { however, intercalated with sandstone beds } \\
\text { of distinctly coarser grain size and poorer } \\
\text { sorting. When this facies overlies facies B, } \\
\text { the intercalated beds are closer in } \\
\text { appearance to that and internally } \\
\text { characterized by cosets of small troughs } \\
\text { only (subfacies E }{ }_{B} \text { ). When overlies facies } \\
\text { association D it is more akin to that and } \\
\text { internally characterized by cosets of small } \\
\text { troughs passing laterally into low angle } \\
\text { cross-strata of larger set thickness } \\
\text { (subfacies E } \text { D). The facies is laterally } \\
\text { extensive, have tabular geometry and base } \\
\text { always demarcated by a thin and broadly } \\
\text { wavy laterally persistent well-sorted } \\
\text { granule lag. Granular lags, albeit laterally } \\
\text { impersistent, are present, also at the base } \\
\text { of wave-featured beds in subfacies Es). }\end{array}$ & $\begin{array}{l}\text { and wave-dominated deposits and position } \\
\text { of its single unit just beneath the } 10 \text { s of } \\
\text { meters thick entirely wave featured marine } \\
\text { or lacustrine stratigraphic segment } \\
\text { (discussed below) this facies is identified as } \\
\text { transitional between the fluvial and } \\
\text { marine/lacustrine environments. }\end{array}$ \\
\hline
\end{tabular}




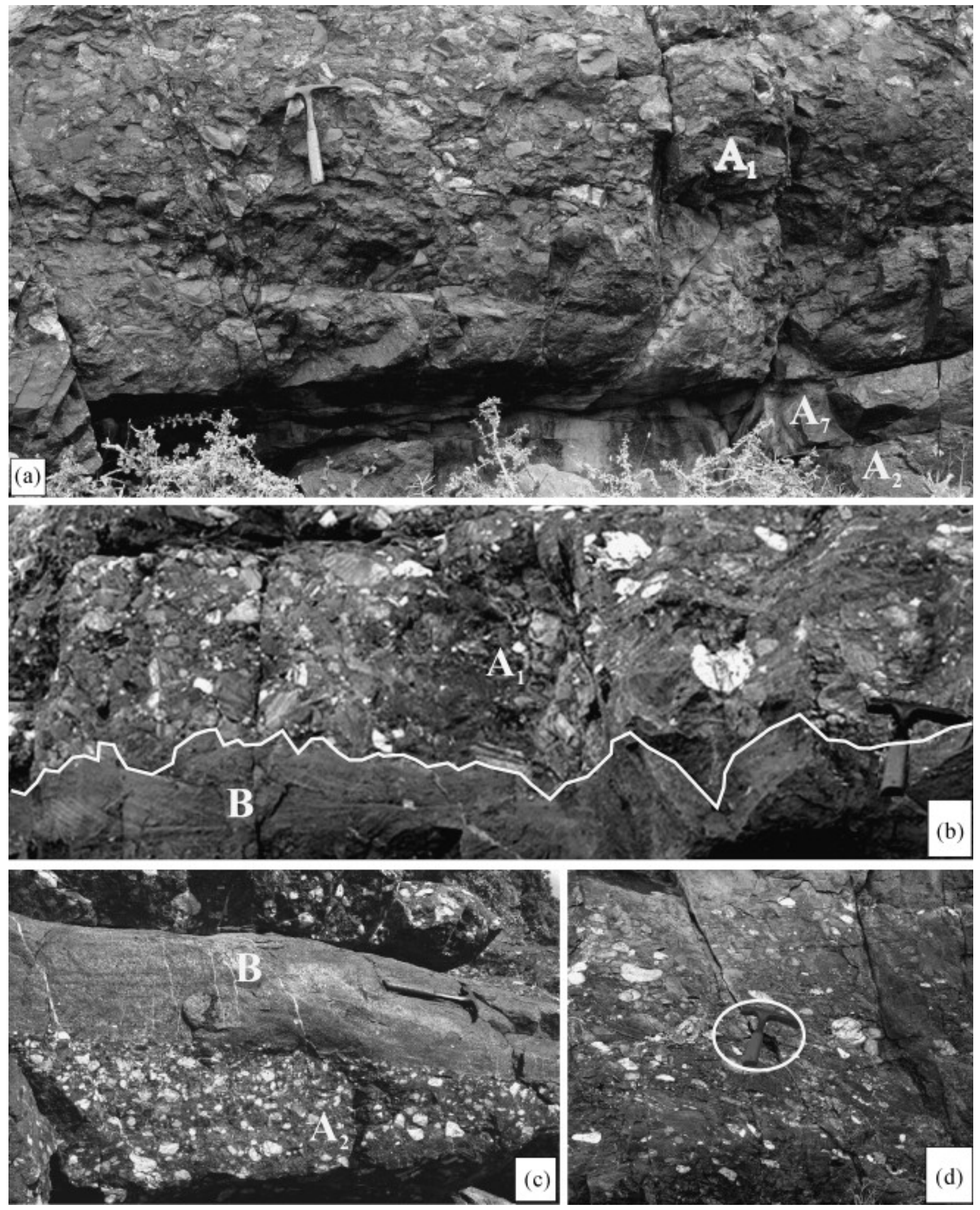



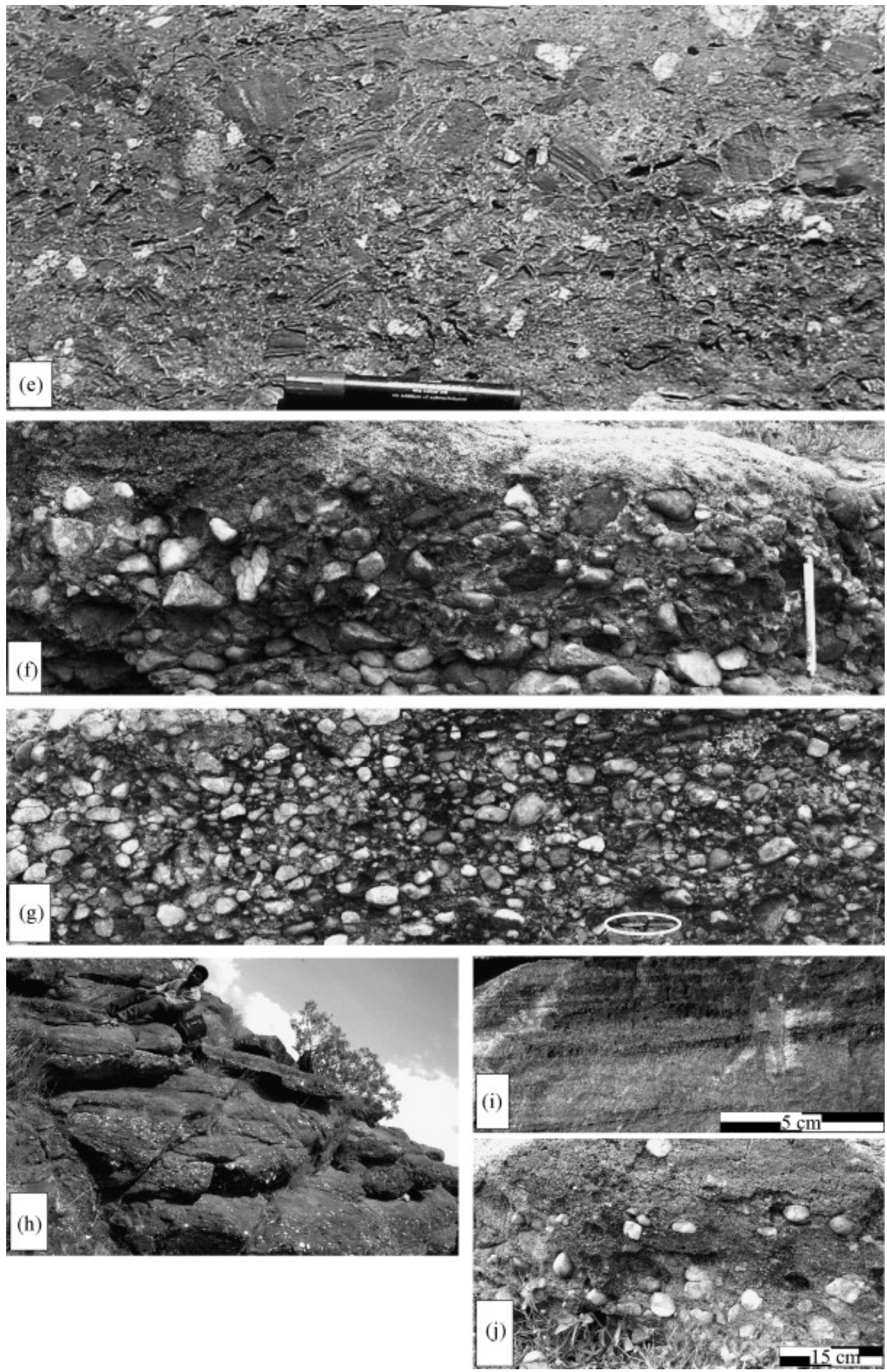
Fig. 2. Facies in Salgundi Conglomerate Member: (a) Scree breccia $\left(A_{1}\right)$ overlying a hillwash $\left(A_{7}\right)$ that, in turn, overlies a debris-flow conglomerate $\left(A_{2}\right)$ at Ramthal. Note, angular tabular shape of the clasts, lack of matching boundaries between adjacent clasts and clast-supported fabric within facies $A_{1}$. (b) Scree facies $\left(A_{1}\right)$ overlying a small channel facies (B) near the top of the proximal section at Salgundi. Note strongly jagged base of the scree because of deep clast penetration. (c) Debris-flow facies $\left(A_{2}\right)$ underlying a streamlet facies (B) at Salgundi. Note irregular top of the debris-flow body. (d) Longaxis pebble imbrication in facies $\mathrm{A}_{3}$, internally sheared debris-flow at Salgundi. (e) Modified grainflow facies $\left(\mathrm{A}_{4}\right)$ with reverse grading at Salgundi (pen length $12 \mathrm{~cm}$ ). (f) Sieve facies $\left(\mathrm{A}_{5}\right)$ at Bilgi, with greater sand infiltration upward changing the basal clastsupported fabric into a matrix-supported fabric (pen length $13 \mathrm{~cm}$ ). (g) Sheet-flow facies $\left(\mathrm{A}_{6}\right)$ at Bilgi. Note clast-supported fabric and preferred leftward intermediate-axis imbrication of clasts (pen length $14 \mathrm{~cm}$ ). (h) Small channel facies (B) characterized by numerous small channels juxtaposed laterally and vertically. Note pebble lag at base of the channels. (i) Trough cross-strata followed upward by planar laminae in channel-fills within small channel facies (B) at Salgundi. (j) Pebbly flash-flood deposit within facies B. Note crude cross-strata and pebbles reclining on the foresets. 

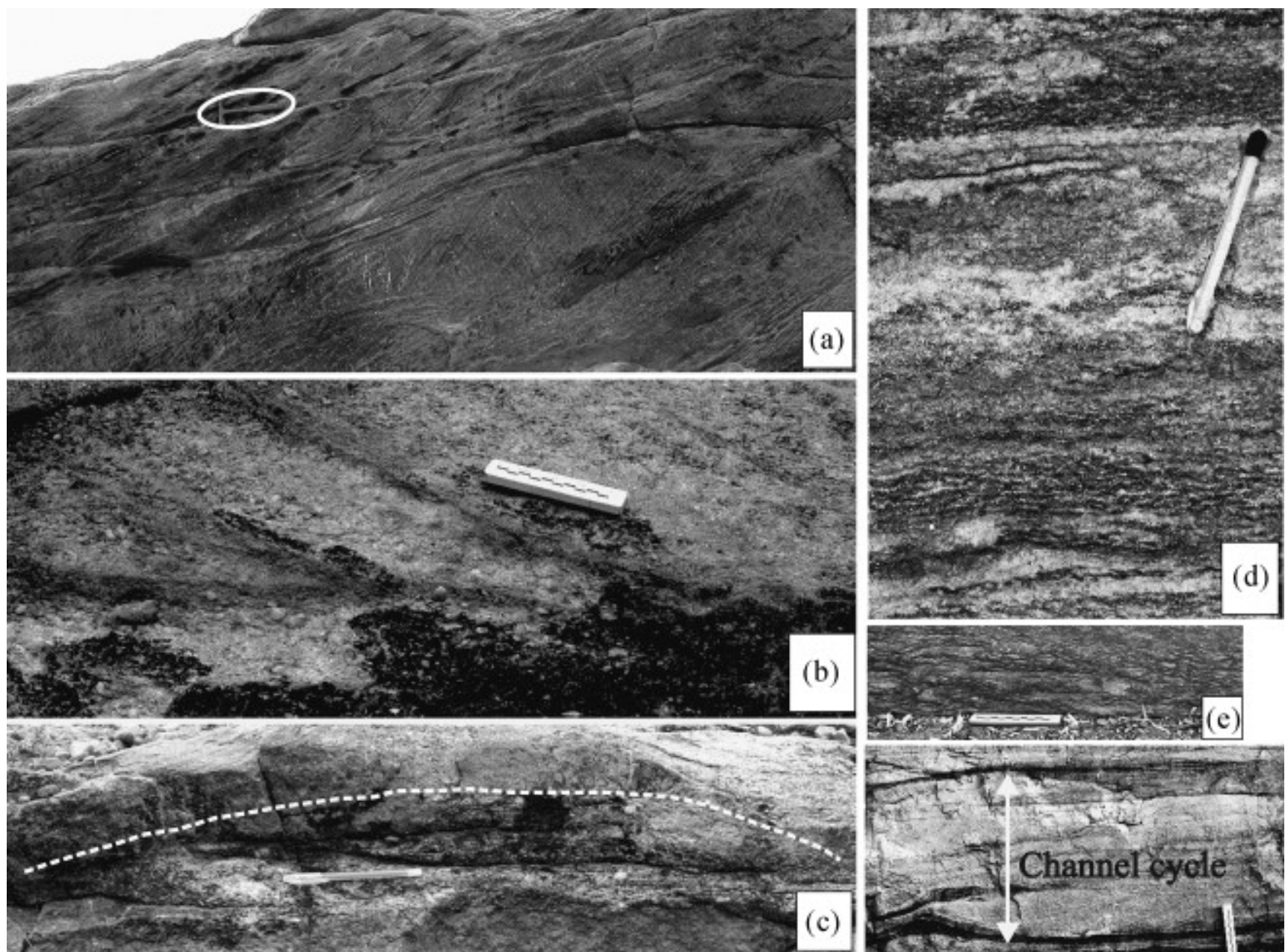

(b)

(c)

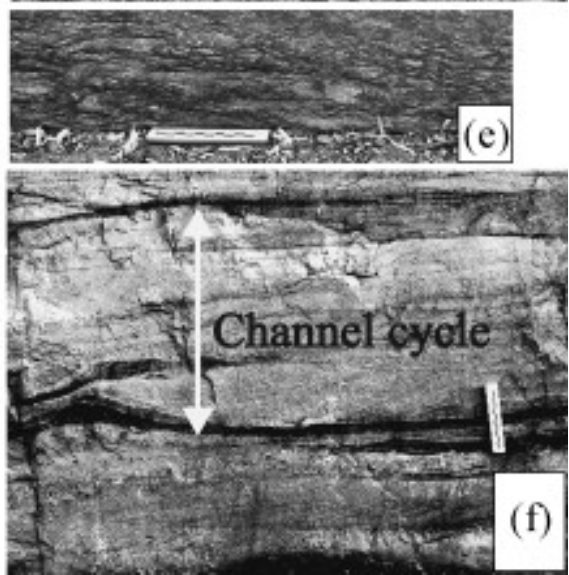

Fig. 3. (a) A longitudinal bar with Downstream Accretion Element (DAE) in facies $\mathrm{C}_{1}$.

(b) Scalloped base of foresets within a bar in facies $C_{1}$ (bar length $10 \mathrm{~cm}$ ). (c) Transverse section of a bar in facies $C_{1}$ displaying vertically accreted layers (one layer-interface highlighted, pen length $13 \mathrm{~cm}$ ). (d) Adhesion laminae below and above the match stick (length $2.5 \mathrm{~cm}$ ). (e) Translatent strata within facies $\mathrm{C}_{1}$ (bar length $10 \mathrm{~cm}$ ). (f) A complete channel-floor facies, $\mathrm{C}_{4}$, unit (centre) bounded by concave-up base and nearly flat top, both well demarcated by thick ferruginous coats (dark): relics of similar coats in between cross-stratified beds indicate breaks in sedimentation. 

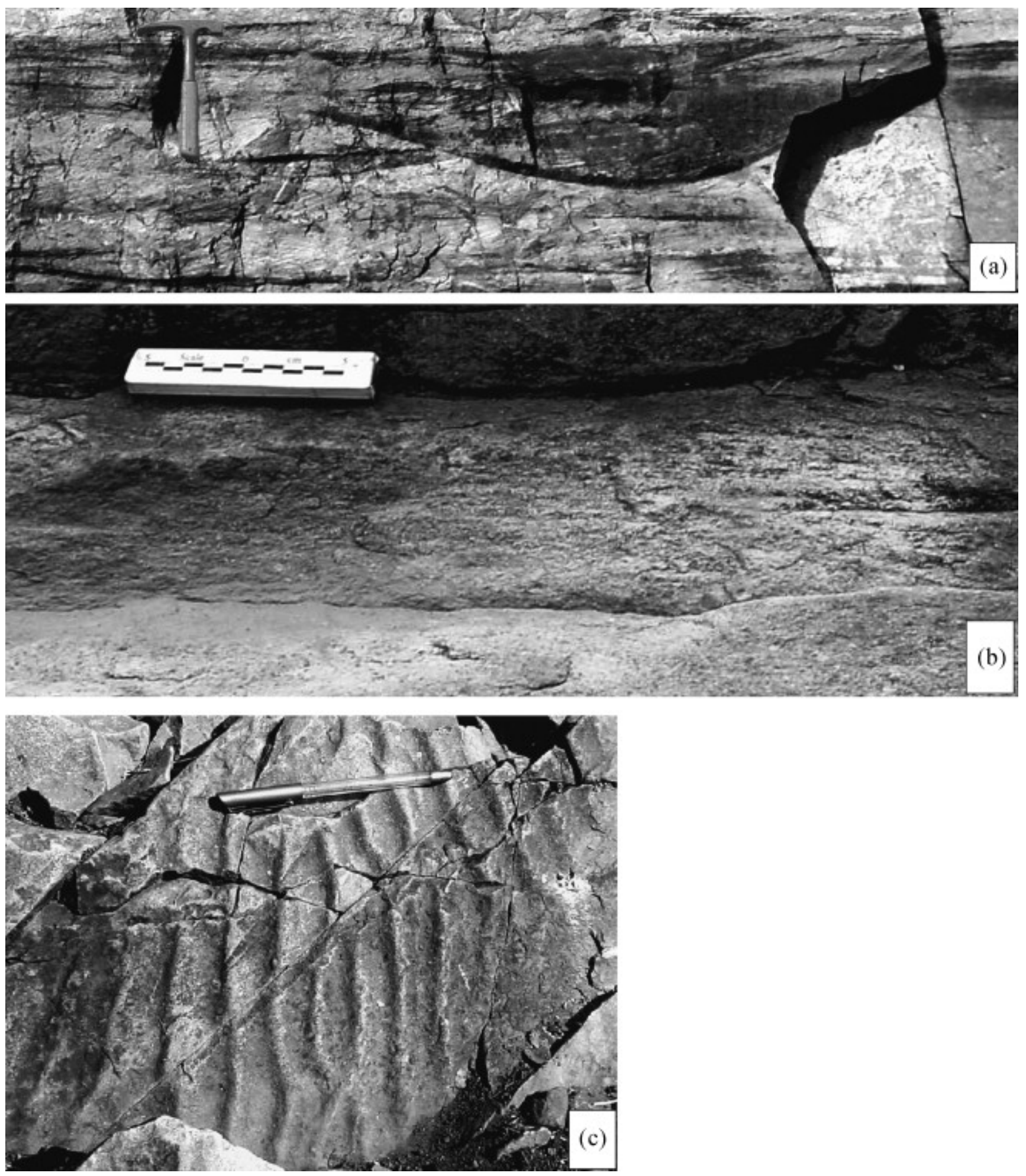

Fig. 4. (a) Small bar-top scour in facies $\mathrm{D}_{1}$ at Ramthal. (b) Fine-grained planar laminae in facies $\mathrm{D}_{2}$. (c) Wave ripples in transitional facies $\mathrm{E}$ at Salgundi (pen length $13 \mathrm{~cm}$ ). 
The facies association A is the coarsest among all and is presumed to have been closest to the basin-margin. Its scree-breccias of inferred rock-fall origin possibly accumulated at the base of steep fault-scarps, generally delimiting the sedimentary basin. Various lensshaped constituents of this association, including the scree juxtapose each other, laterally and vertically, giving rise to a facies mosaic. It locally incorporates isolated or clustered lenses of facies B. In turn, isolated lenses of association A's conglomeratic facies, comparatively finer grained, occur where sandy facies B or the association C dominates, presumably at some distance from the basin-margin. Facies association $\mathrm{D}$ and facies $\mathrm{E}$ are, however, completely free of A-type consituents and constitute the finest grade of sediment in the studied assemblage, and were possibly deposited farthest from the sediment entry points into the basin.

\section{Facies architecture}

Facies architecture at Ramthal and Salgundi was perceived on visual appreciation of both lateral and vertical transitions, but is framed here on the basis of measured vertical facies successions at three different spots in two of the field locations, moving successively downslope away from the basin-margin, along the river-flow direction, as much as the outcrops permit. The vertical sections are accordingly named below as 'proximal', 'middle' and 'distal' for these two field locations. At the Bilgi location, however, exposures only allowed erection of a single continuous synthetic vertical section, moving in the dip direction, up a gentle hill-slope.

\subsection{Location 1, around Ramthal (Fig. 1 and Fig. 5)}

Sections at both ends of the roughly downslope stretch of $200 \mathrm{~m}$ have the metasedimentary basement exposed underneath (Fig. 5). 


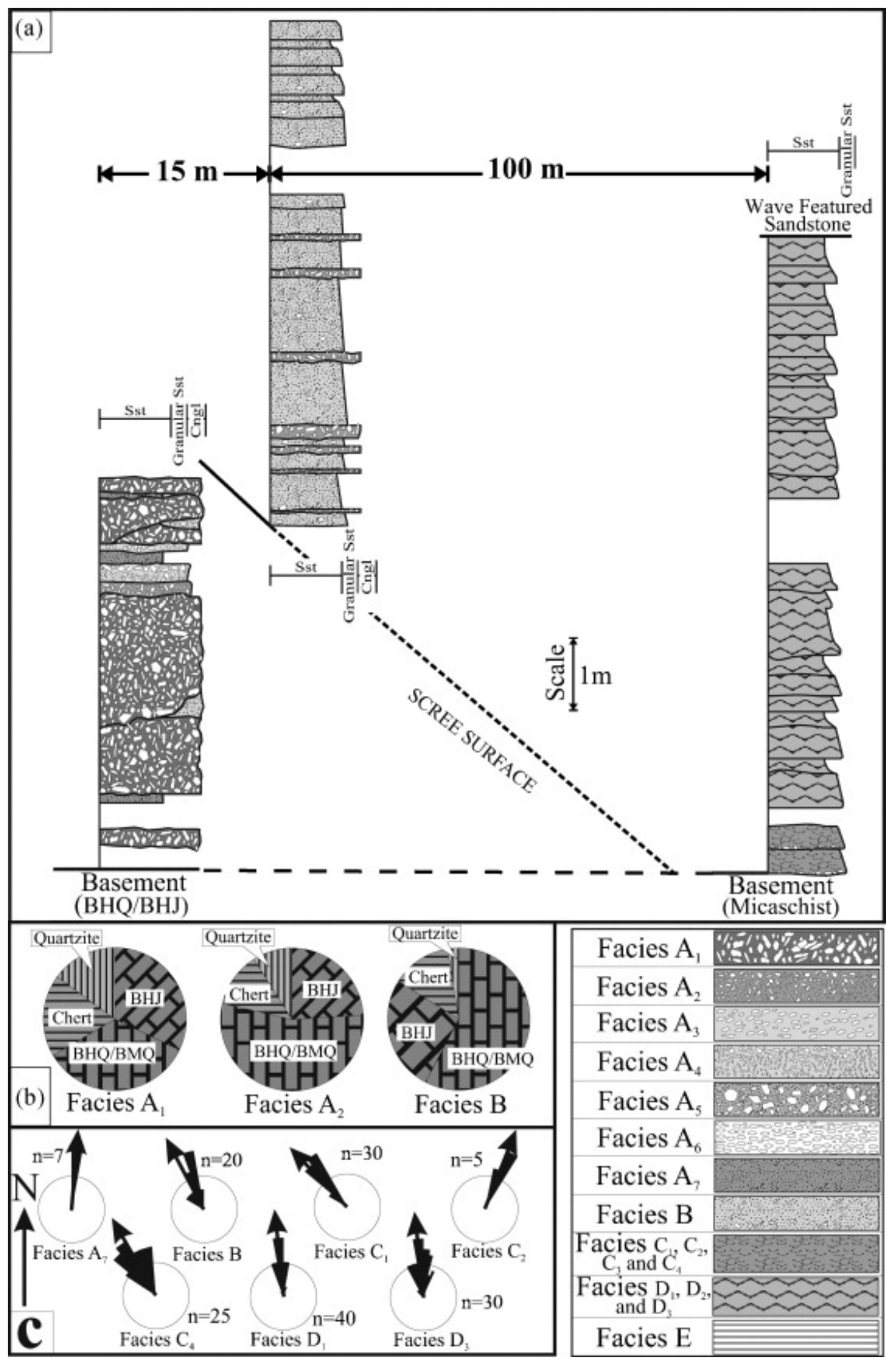


Fig. 5. (a) Basin-margin facies distribution in three sections moving along dip direction from left to right at location Ramthal, with tentative reconstruction of the scree cone surface. (b) Clast composition in breccia and conglomerate of different origin. (c) Crossstrata azimuths in different sandy facies. Symbols used for the facies comprising the stratigraphic segments under focus in all three study locations are presented at the bottom right.

\subsubsection{Proximal section}

Five distinctive facies, viz., scree $\left(A_{1}\right)$, debris-flow $\left(A_{2}\right)$, modified grain-flow $\left(A_{4}\right)$, hill wash $\left(A_{7}\right)$ and streamlet facies (B) (Table 1) comprise this section, resting directly on BIF (Fig. 5a). All breccias and conglomerates are made up of clasts derived largely, if not entirely, from the immediate basement of iron formation (Fig. 5b). The scree breccia beds dominate by far, and are disparately thicker and coarser than any other conglomerate bed in the entire Bagalkot Group; they rapidly wedge out in the downcurrent direction. Trough cross-strata of facies $\mathrm{A}_{7}$ and $\mathrm{B}$ have discrete orientations, but the former facies yielded only seven readings in a single bed (Fig. 5c). For both the cases, however, the orientation is remarkably consistent, irrespective of relative positions of the sections, proximal, middle or distal.

\subsubsection{Middle section}

This section, just $15 \mathrm{~m}$ downcurrent from the inferred proximal section rests, at least partially, on the scree breccia at its upcurrent or upslope margin. It is dominantly sandy, comprising two distinct facies, viz. the dominant streamlet facies (B) infrequently intervened by thin debris-flow facies $A_{2}$ (Fig. 5a). However, facies $A_{4}$ characterized by reverse grading, that is closely associated with facies $A_{2}$ in the proximal section, is absent in this medial section.

\subsubsection{Distal section}

This section, situated about $100 \mathrm{~m}$ away from the middle section in the depositional dip direction, is made up mostly of fluvial facies $\mathrm{D}_{1}, \mathrm{D}_{2}$ and $\mathrm{D}_{3}$, except in a thin basal 
segment occupied by facies $\mathrm{C}_{1}$ (Fig. $5 \mathrm{a}$ ). The section rests directly on the basement rock, mica schist.

\subsubsection{Interpretation}

The proximal section at Ramthal suggests a base-of-slope scree cone deposit. Deep penetration of clasts into the sediment substratum rupturing many of its internal laminae, a general absence of matching, mutually fitting boundaries between adjacent clasts, the high angularity of the clasts, their derivation from the basement in the immediate vicinity together strongly support the inferred scree or rockfall (sensu stricto) origin of the dominant facies, $A_{1}$. Occasional mild rainfall-induced deposition is inferred from the interpreted hillwash facies $\left(A_{7}\right)$ that covered the surfaces of instantaneously deposited scree beds. The presence of current-generated structures, though poorly preserved, indicates a relatively low density for the flows depositing $A_{7}$. However, the inferred debris-flow $\left(A_{2}\right)$ and sheared mass flow $\left(A_{3}\right)$ deposits are interpreted to reflect high density, coarse-grained, rain-induced flows which occasionally turned viscous and deposited these facies. Higher particle concentrations in these mass-flows might have led to deposition of occasional modified grain flow deposits $\left(\mathrm{A}_{4}\right)$, The dominantly crossstratified streamlet facies B, on the other hand, is ascribed to fluidal traction currents induced by heavy rainfall. The common presence of planar laminae on top of trough cross-strata within palaeochannel confinement in this facies, indicates late-stage sheet flow deposition (Olsen, 1989). Facies $A_{7}$ cross-strata, which maintain a very high degree of palaeocurrent consistency suggest a straight course for hill wash, presumably owing to the steep slope of the scree cone. Their high angle relationship with palaeocurrent trends in facies B, may suggest local slope control on the hill wash. Superproximal terrestrial palaeogeography, immediately adjacent to the basin-margin is implied for the facies assemblage of this section.

Facies B dominance in the middle section in the Ramthal field area suggests deposition mainly through a network of incised channels. The hillwash facies that is absent in this section apparently remained confined to the proximal site. Randomly scattered over-sized

pebbles within many facies B channel-fill sandstones depict rapid deposition from high- 
velocity flash floods ([Frostick and Reid, 1989] and [Pfluger and Seilacher, 1991]). Debris-flows occasionally encroached upon this inferred 'middle' depositional site, but the modified grain flows (Facies $\mathrm{A}_{4}$ ) also presumably froze on the scree cone itself because of rapid release of potential energy on the steep scree slope ([Campbell, 1989], [Campbell et al., 1995] and [Peakall et al., 2001]). Deposition apparently took place lower down on the scree cone. Up-section, interbedded debris-flow facies become progressively reduced in frequency, and facies B palaeo-channels become wider, the preserved width of channels increasing from $1.5 \mathrm{~m}$, on average, in the preceding proximal section to $4 \mathrm{~m}$ in this middle section. Progressive slope reduction of the sedimentary cone is inferred. Facies $B$ occurs, though only occasionally, in association with facies $A_{1}, A_{2}$, $A_{4}$ and $A_{7}$ in the proximal section at Ramthal, but there it tends to segregate from those four coarser grained facies implying deposition in a relatively distal palaeogeographic position.

Mass-flows as well as facies B apparently did not encroach upon the inferred distal site at Ramthal, and the pebble-free and thoroughly stratified fluvial facies $\mathrm{D}_{1}, \mathrm{D}_{2}$ and $\mathrm{D}_{3}$ make up almost the entire section, with facies association $\mathrm{C}$ forming only a thin unit at its base. Decrease in grain size and fine stratification in the sandstone indicate rapid reduction in flow velocity and sedimentation rate, presumably on an alluvial plain fringing the scree cone. Palaeocurrent patterns inferred from troughs, large and small, in both the facies associations $\mathrm{C}$ and D still maintain a high consistency (Fig. 5c).

\subsection{Location II, Salgundi Hill (Fig. 1 and Fig. 6)}

\subsubsection{Proximal section}

This measured section is dominated by conglomerate and is upward-coarsening (Fig. 6a), its basal part being more sandy than conglomeratic. Clast composition is variable, indicating contribution to the sediment budget from both the plutonic and metasedimentary sources (Fig. 6b). Five pebbly facies, viz. inferred debris-flow $\left(A_{2}\right)$; sieve $\left(A_{5}\right)$, sheet conglomerate $\left(A_{6}\right)$, streamlet $(B)$ facies and very rare scree facies $\left(A_{1}\right)$ (Table 1) constitute this section (Fig. 6a). 


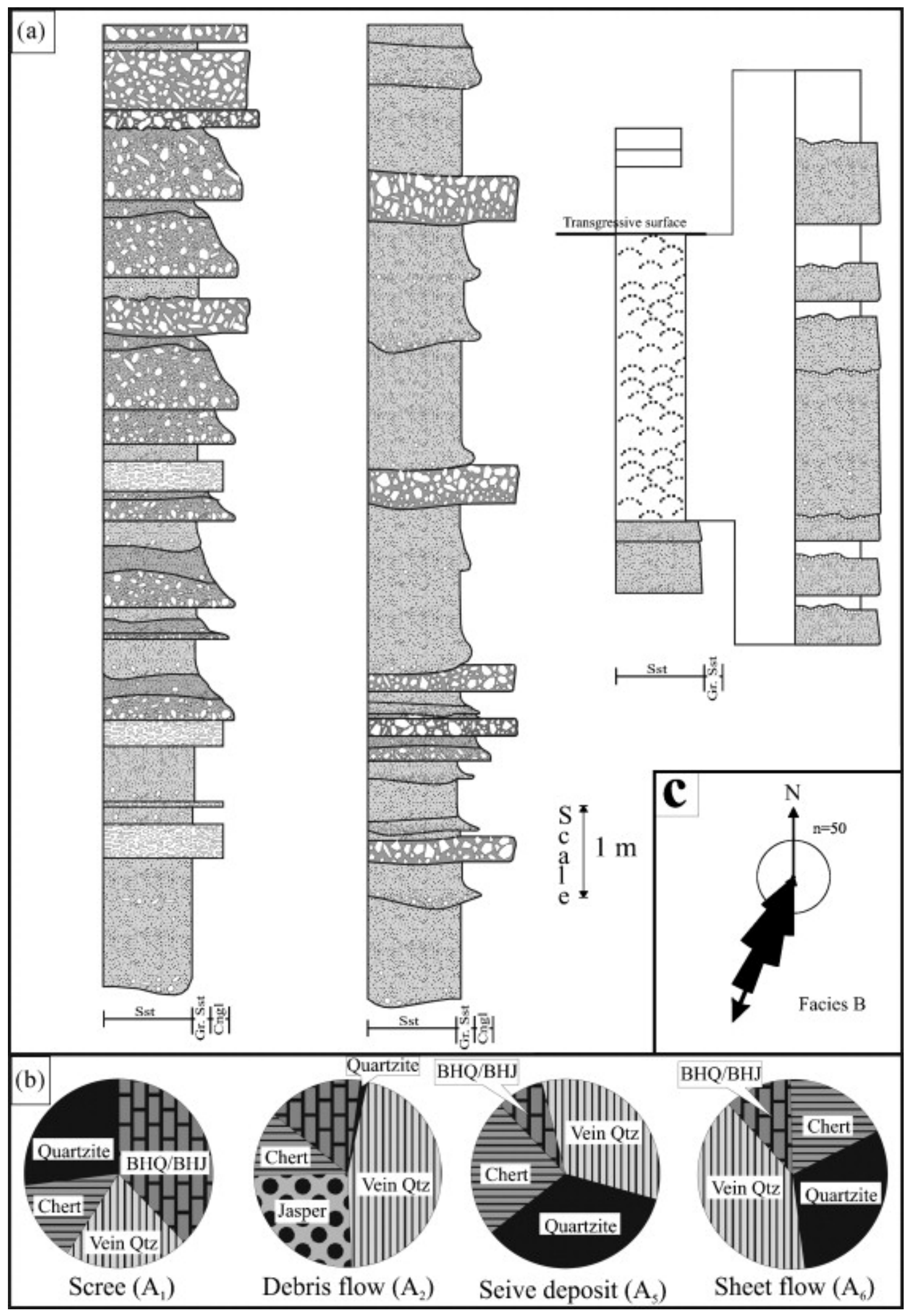


Fig. 6. (a) Facies distribution in three sections moving in dip-parallel direction from left to right at location Salgundi (for symbols see Fig. 5). (b) Clast composition in conglomeratic facies of varied origins. (c) Cross-bedding azimuth in small channel facies (B).

\subsubsection{Middle section}

This section consists of three of the inferred proximal facies, viz. $A_{2}, A_{5}$ and $B$ with rare occurrence of the sheared mass-flow conglomerate facies $\mathrm{A}_{3}$ (Fig. 6a). Conglomerate beds thicken upward; however, amalgamated conglomerate beds, though rare, occur in the lower portion of the measured section. No significant segregation of any facies exists in any part of the section. Clast composition in conglomerates in this and the proximal section indicates that though the metasedimentary basement rocks contributed substantially to the sediment budget, a large share of vein quartz came possibly from the granitic basement (Fig. 6b)

\subsubsection{Distal section}

This section is made almost entirely of the sandy transitional facies (E) before passing upward into thick wave-featured sandstones deposited in the inferred standing body of water. Here this facies is made up of interbedding between thin facies B-equivalents (subfacies $\mathrm{E}_{1}$ ) and the wave-featured component. A single $70 \mathrm{~cm}$ thick facies B unit, however, occurs at the base of this section and is terminated by a thin laterally extensive and well-sorted granule lag before passing upward into subfacies $E_{B}$ (Fig. 6a). Facies associations $C$ and $D$ are altogether absent. The subfacies $E_{B}$ unit overall fines upward with increasing dominance of relatively finer grained wave-featured sandstone. Orientation of cross-strata, combining readings from all the facies B units and Bequivalent units within subfacies $\mathrm{E}_{\mathrm{B}}$, irrespective of wide variability in their stratigraphic positions, is fairly consistent (Fig. 6c).

\subsubsection{Interpretation}

The profound coarsening-upward trend in the proximal section with increasing abundance of coarse-grained mass-flow products supports progradation of an alluvial fan 
formed in a semi-arid climate (cf. [Rust and Koster, 1984], [Nilsen, 1985] and [Blair and McPherson, 1994]). The basal part of the inferred proximal fan section is made entirely of facies B channeled sandstones and indicates deposition below the intersection point between the fan surface and the water table (e.g., [Heward, 1978] and [Talbot and Williams, 1979]). The immediately overlying assemblage, dominated by sieve $\left(A_{5}\right)$ and sheet $\left(A_{6}\right)$ facies with subordinate incorporation of streamlet $(B)$ facies and rare debrisflow $\left(\mathrm{A}_{2}\right)$ facies, possibly formed immediately beneath the intersection point (cf. [Hooke and Le, 1967] and [Rahn, 1967]). However, it should be noted that sieve deposits typically occur in proximal fan regions or during early stages of fan growth, with sheetflood deposits forming in either medial or lower fan segments depending on stage of fan development (see Blair and McPherson, 1994; their Figures 20-22). Thickness of this medial assemblage in the proximal measured section at Salgundi Hill of ca. $6 \mathrm{~m}$ can be attributed to movement of the water table up and down the fan, seasonally or in a longer cycle. In contrast, the debris-flow facies, along with a few units of sieve $\left(A_{5}\right)$ facies, sheared mass flow $\left(\mathrm{A}_{3}\right)$ facies as well as streamlet $(\mathrm{B})$ facies, dominates the topmost part of this measured section, made of the coarsest sedimentary rocks and had presumably been deposited above the intersection point and near the apex of the fan. The isolated minor facies B channels, floored by pebble lags which pinch out in the direction that the internal channel-fill cross-strata dip into, possibly reflect river channels well above the intersection point, disappearing rapidly because of water percolating downward through loose and coarse sediment, and also joints, fractures and other pore spaces in the basement rock to re-emerge only at the 'intersection' level. Occurrence of inferred scree deposits within this top part of the fan (Fig. 6a) suggests considerable relief generation and thereby implies tectonic uplift of the basement interrupting basin-filling. In the inferred mid-fan section at Location II, Salgundi Hill, facies B dominates, whereas thin facies $A_{2}$ occurs locally, and facies $A_{5}$ is very rarely interbedded. Traction current dominance and rare extension of mass-flow lobes, presumably below the 'intersection' level is implied. The distal measured section at Salgundi Hill, on the other hand, has facies $B$ only at its base, but is otherwise made up of subfacies $E_{B}$ only, before passing upward into the thick wave-featured sandstone deposited in the standing body of water, whether lake or sea. Deposition at this site presumably took place well below the 
intersection point, at the distal fan fringe that was intermittently encroached upon by a standing body of water. The studied basin-margin sediment pile at the Salgundi location should, as a whole, better be called a combination of a fan and a fan-delta, and more specifically, a shallow water, shelf-type fan-delta (cf. [Nemec and Steel, 1984], [Massari and Colella, 1988], [Postma, 1990] and [Wescott and Ethridge, 1990]). Subfacies EB at the distal section depicts pulsatory transgression of the standing body of water, and the granular lag at its base presumably formed when the standing body of water encroached upon the fan. Laterally discontinuous granular lags within the subfacies are possibly of wave-winnowing origin ([Clifton, 1973] and [Levell, 1980]).

\subsection{Location III, Bilgi Hill (Fig. 1 and Fig. 7)}

The single section measured here, moving up the steady gentle southern slope of Bilgi Hill, is conglomeratic in its basal $2 \mathrm{~m}$ only and sandy, but still carrying pebbles or grit almost throughout the rest of the section (Fig. 7a). While pebble population in the conglomerate is generally better sorted and the clasts are smaller at this location, the sandstone is almost always very poorly to moderately sorted. The majority of the pebbles appear to have been derived from the nearby granitic basement (Fig. 7b). 


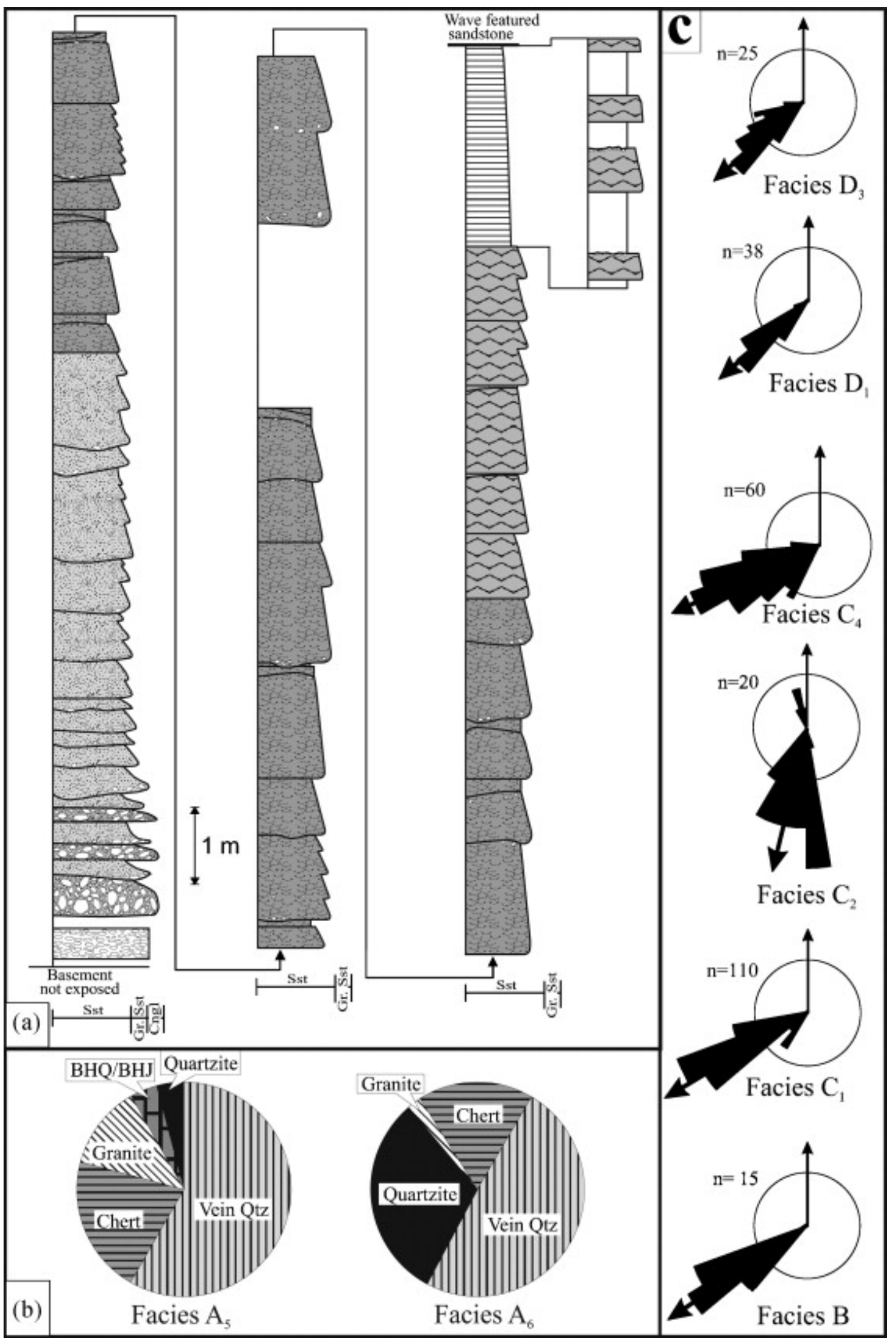


Fig. 7. (a) Basin-margin facies distribution in Bilgi section (for symbols see Fig. 5), highlighting vertical variation in relative thickness between wave-featured sandstone and facies association D-equivalent within facies E. (b) Clast composition variation in conglomeratic facies and (c) facies-specific cross-strata azimuths are on right. Conglomeratic sieve $\left(\mathrm{A}_{4}\right)$ and sheet $\left(\mathrm{A}_{6}\right)$ facies dominate the basal part, while in the rest of the section the streamlet facies (B) is followed upward by facies association C, the latter enclosing the inferred aeolian patches (facies $\mathrm{C}_{1}$ ). Facies association $\mathrm{D}$ that succeeds the facies association $\mathrm{C}$ is very thin, around $4 \mathrm{~m}$. Further upward the transitional subfacies $E_{D}$ dominates at the topmost part of the section, within which wave-featured beds thicken upwards at the cost of the former. The Bilgi section, as a whole, is finingupward, even across the granule lag at the base of non-repetitive subfacies $E_{D}$. Orientation of large and small trough cross-strata within facies B, associations C, D and in the D-equivalent fluvial component within subfacies $E_{D}$ is, once again, fairly consistent (Fig. 7c).

\subsubsection{Interpretation}

The conglomerates remaining almost entirely confined to the basal segment, the section most probably reflects the distal fringe of an alluvial fan, the proximal part of which, presumably, has not been preserved. Facies B and association C sandstones that overlie this conglomerate are interpreted as pebbly fluvial deposits, intervened by lenses of inferred high-velocity flash flood deposits. Deposition is thought to have taken place within a distal fan setting with a reasonable gradient. In contrast, the pebble-free fluvial facies association D, overlying facies association C, though thin, was perhaps deposited beyond the fan fringe and may represent fluvial deposition on an adjacent plain. Further upward in the succession, subfacies $\mathrm{E}_{\mathrm{D}}$ records interfingering between the fluvial environment and the standing body of water. The granular lag at the base of this subfacies is a transgressive lag, as in case of $\mathrm{E}_{\mathrm{B}}$, and the vein quartz and chert clasts in this lag were likely derived from the facies association $\mathrm{C}$ lying at shallow depth. A river course, though short, thus apparently separated the alluvial fan and the standing body of water. 


\section{Fluvial architectural elements and their packaging}

Fluvial architectural elements (based on those described in Miall, 1996) in the studied stratigraphic interval of the Ramdurg Formation are described for the fluvial facies B and E (fluvial components) and facies associations C and D, and are interpreted in Table 2.

Table 2.

Fluvial archtectural elements

\begin{tabular}{|c|c|c|c|}
\hline $\begin{array}{l}\text { Architec- } \\
\text { tural } \\
\text { element }\end{array}$ & Description & Interpretation & $\begin{array}{l}\text { Facies } \\
\text { constituents }\end{array}$ \\
\hline $\begin{array}{l}\text { Downstream } \\
\text { accretion } \\
\text { element }\end{array}$ & $\begin{array}{l}\text { Convex upward sandstone } \\
\text { bodies, with or without } \\
\text { granules and pebbles, } \\
\text { internally characterized by } \\
\text { large-scale trough cross- } \\
\text { beds, confining smaller } \\
\text { down-dip trough cross- } \\
\text { strata while making angle } \\
\text { lesser than } 15^{\circ} \text { with } \\
\text { bedding (Fig. 3a). Both } \\
\text { large and small cross- } \\
\text { strata dip in the same } \\
\text { direction (Fig. 8a). }\end{array}$ & $\begin{array}{l}\text { Inferred as bar. Ripples } \\
\text { from stoss of the bar } \\
\text { moved down its lee face } \\
\text { when that turned gentler. }\end{array}$ & $\begin{array}{l}\mathrm{C}_{1}, \mathrm{D}_{1} \text { and } \mathrm{E} \\
\text { (low angle single } \\
\text { set of cross-strata } \\
\text { in E possibly the } \\
\text { toe part of bar). }\end{array}$ \\
\hline $\begin{array}{l}\text { Lateral } \\
\text { accretion } \\
\text { Element }\end{array}$ & $\begin{array}{l}\text { Inclined sheet of tabular } \\
\text { cross-stratified sandstone } \\
\text { free of granule or pebble. } \\
\text { In up-dip direction the } \\
\text { sheets, at places, found } \\
\text { reclined on the flank of } \\
\text { convex-up DA element } \\
\text { bodies and LSE (described } \\
\text { below) may overlie them } \\
\text { (Fig. 8b). Cross-strata dip } \\
\text { direction is at high angle }\end{array}$ & $\begin{array}{l}\text { Accretion evidently took } \\
\text { place at high angle to bar } \\
\text { migration direction. } \\
\text { Relationship with DA } \\
\text { and LS identifies this } \\
\text { element not as a bank- } \\
\text { attached bedform, but as } \\
\text { bar-flank accretion. Sand } \\
\text { that was transported } \\
\text { across the bar crest } \\
\text { apparently avalanched }\end{array}$ & Facies $\mathrm{C}_{3}$. \\
\hline
\end{tabular}




\begin{tabular}{|c|c|c|c|}
\hline $\begin{array}{l}\text { Architec- } \\
\text { tural } \\
\text { element }\end{array}$ & Description & Interpretation & $\begin{array}{l}\text { Facies } \\
\text { constituents }\end{array}$ \\
\hline & $\begin{array}{l}\text { to that of DA (Fig. } 5 \text { and } \\
\text { Fig. 7). Measured } \\
\text { maximum vertical height } \\
\text { of the element is } 20 \mathrm{~cm} \\
\text { and outcrop length nearly } \\
\text { a meter. }\end{array}$ & $\begin{array}{l}\text { down the bar flank. } \\
\text { Existence of a secondary } \\
\text { flow is implied and it } \\
\text { presumably became } \\
\text { effective when the } \\
\text { along-channel flow } \\
\text { driving the bars } \\
\text { declined. }\end{array}$ & \\
\hline $\begin{array}{l}\text { Laminated } \\
\text { sand-sheet } \\
\text { element }\end{array}$ & $\begin{array}{l}\text { Thin sand sheets, may or } \\
\text { may not be granule-rich, } \\
\text { characterized internally by } \\
\text { planar laminae and on bed- } \\
\text { top by parting lineation. } \\
\text { Overlies the preceding } \\
\text { elements (Fig. 8c). }\end{array}$ & $\begin{array}{l}\text { Formed during low flow } \\
\text { stage reworking } \\
\text { sediment already settled } \\
\text { on top of DA and LA } \\
\text { elements. }\end{array}$ & $\mathrm{C}_{2}$ and $\mathrm{D}_{2}$. \\
\hline $\begin{array}{l}\text { Small } \\
\text { channel } \\
\text { element }\end{array}$ & $\begin{array}{l}\text { Sandstone, pebbly or not, } \\
\text { lenticular in geometry. } \\
\text { Internally characterized by } \\
\text { cosets of small-scale } \\
\text { trough cross-strata. Base } \\
\text { generally concave-up, but } \\
\text { convex upward when } \\
\text { overlying isolated bodies } \\
\text { of SB or SGF elements } \\
\text { described below. Top } \\
\text { generally flat. Maintain } \\
\text { onlap or downlap } \\
\text { relationship with DA and } \\
\text { LA elements when } \\
\text { associated. Maximum } \\
\text { measured outcrop width } \\
\text { exceeds } 100 \text { m along } \\
\text { current direction and }\end{array}$ & $\begin{array}{l}\text { Small channels. When } \\
\text { associated with DA and } \\
\text { LA considered as } \\
\text { channel-floor deposit in } \\
\text { between bars-related } \\
\text { elements. }\end{array}$ & $\begin{array}{l}\text { Facies } \mathrm{B}, \mathrm{C}_{4}, \mathrm{D}_{3} \text {, } \\
\mathrm{E} \text { (cosets of } \\
\text { small scale } \\
\text { troughs) }\end{array}$ \\
\hline
\end{tabular}




\begin{tabular}{|c|c|c|c|}
\hline $\begin{array}{l}\text { Architec- } \\
\text { tural } \\
\text { element }\end{array}$ & Description & Interpretation & $\begin{array}{l}\text { Facies } \\
\text { constituents }\end{array}$ \\
\hline & thickness $<2 \mathrm{~m}$. & & \\
\hline $\begin{array}{l}\text { Sandy } \\
\text { bedform } \\
\text { element }\end{array}$ & $\begin{array}{l}\text { Made of pebbly sandstone, } \\
\text { characteristically having } \\
\text { convex-up geometry and } \\
\text { internal cross-strata, } \\
\text { mostly crude. Pebbles tend } \\
\text { to concentrate at the base } \\
\text { and generally reclined on } \\
\text { the crudely defined } \\
\text { foresets. Outcrop width } \\
\text { and vertical height of this } \\
\text { element are } 2 \text { m and } 40 \mathrm{~cm} \\
\text { respectively. }\end{array}$ & $\begin{array}{l}\text { Rapid deposition of } \\
\text { coarse clastics at high } \\
\text { velocity traction current, } \\
\text { possibly during flash } \\
\text { floods, is implied. }\end{array}$ & $\begin{array}{l}\text { Common in } \\
\text { facies B and also } \\
\text { incorporated as } \\
\text { small isolated } \\
\text { bodies within } \\
\text { facies } \mathrm{C}_{4} \text {. }\end{array}$ \\
\hline $\begin{array}{l}\text { Sediment } \\
\text { gravity flow } \\
\text { element }\end{array}$ & $\begin{array}{l}\text { Pebbly sandstone, } \\
\text { lenticular in shape, with } \\
\text { discernible upward } \\
\text { convexity at places and } \\
\text { internally generally } \\
\text { massive (Fig. 8d), but } \\
\text { locally crudely cross- } \\
\text { stratified. Pebbles are } \\
\text { generally chaotically } \\
\text { arranged. }\end{array}$ & $\begin{array}{l}\text { Coarse clastic deposition } \\
\text { from viscous flows, } \\
\text { possibly during flash } \\
\text { floods. Where cross- } \\
\text { stratified, the flow } \\
\text { turned relatively fluidal, } \\
\text { presumably through } \\
\text { sediment shedding. }\end{array}$ & $\begin{array}{l}\text { Common within } \\
\text { facies B and } \mathrm{C}_{4} \\
\text { in form of } \\
\text { isolated lenses } \\
\text { rarely exceeding } \\
5 \mathrm{~m} \text { in width } \\
\text { within B and } 2 \mathrm{~m} \\
\text { in } \mathrm{C}_{4} \text {; vertical } \\
\text { thickness does } \\
\text { not exceed } \\
80 \mathrm{~cm} \text {. }\end{array}$ \\
\hline
\end{tabular}

The fluvial architectural element packaging pattern at the base of the Bagalkot Group is distinctly different for various stratigraphic units dominated by one or more of the inferred fluvial facies and facies associations. For example, facies B, where thick, appears as a mosaic of small channel elements without intervention of any master erosion surface. This package we call type I. 
In contrast, facies associations $\mathrm{C}$ and $\mathrm{D}$ are distinctly divided into multiple architectural element packages, each bounded below and above by laterally persistent master erosion surfaces with distinct iron-oxide coating, unless eroded out. Each of the packages associated with facies association $\mathrm{C}$ is constituted by rows, up to three stacked one above another, of bar-related elements, viz. downstream accretion element, lateral accretion element and laminated sand-sheet element, and small channel elements intervening between them as well as infrequently occurring sandy bed-form elements and sediment gravity flow elements. These packages are $<7 \mathrm{~m}$ thick, roughly tabular in geometry, their bounding surfaces being undulated with incisions often as deep as $0.5 \mathrm{~m}$ (type II) and stacked one above another.

On the other hand, packages within facies association $\mathrm{D}$ are thinner, $<5 \mathrm{~m}$, and sheet-like, with little scouring at base not exceeding $5 \mathrm{~cm}$ in depth (type III). Each of them is constituted only by downstream accretion elements, laminated sand-sheet elements and small channel elements. These packages, in both the facies associations $\mathrm{C}$ and $\mathrm{D}$ are comparable with the channel-belts of Holbrook (2001).

In type IV, typifying the facies $\mathrm{E}$ of the Ramdurg Formation, fluvial beds or bedsets are packaged with marine or lacustrine beds or bedsets, and within the latter the channel elements and bar elements remain laterally juxtaposed. The low angle cross-sets possibly represent toes of largely eroded downstream accretion elements and the laterally adjacent cosets of small troughs constitute the small channel elements between them, as in package type III, with the exception that laminated sand-sheet elements are absent. Lack of master erosion surfaces in package type I is a possible consequence of channel incisions being too frequent and too close to each other. The package pattern that is a hallmark of facies B units suggests formation of a network of interconnected channels, a braided pattern. Omission surfaces conspicuously coated by iron-oxide, often partially eroded, within single channel-fills indicate rapid abandonment and reoccupation of channels (Fig. 3f). So do local occurrences of hydroplastic deformation of cross-beds, resulting in overturning (Fig. 8e). The frequent presence of massive or crudely stratified flash flood deposits incorporating randomly over-sized pebbles further corroborates a 
highly unsteady nature of the flow. Low flow regime bedforms passing upward into high flow regime planar laminae without any discernible decrease in sediment grain-size also points to sheet flow generation for draining out of water from the ephemeral channels (cf., Olsen, 1989).
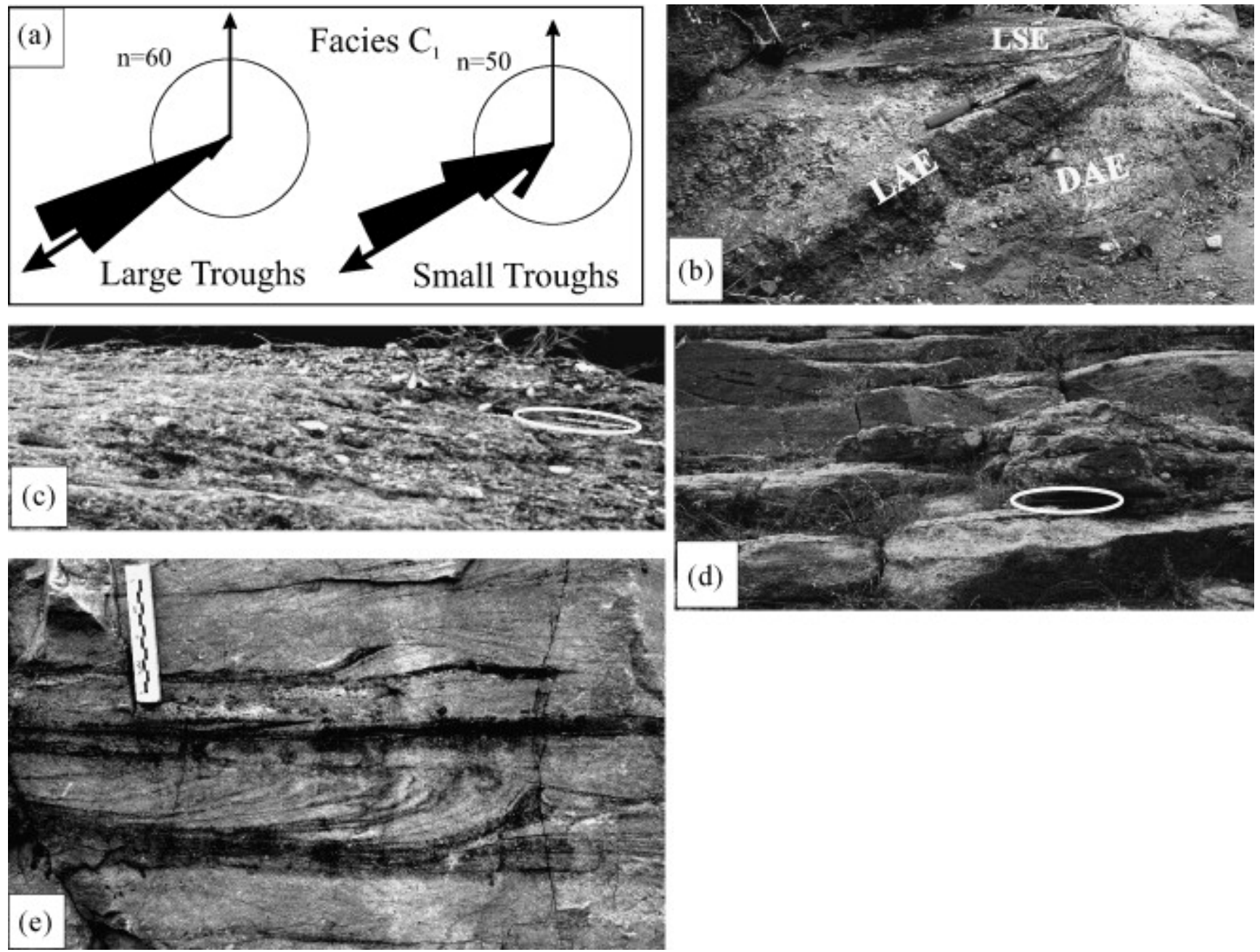

Fig. 8. (a) Similar orientations of small and large troughs within facies $\mathrm{C}_{1}$ at Bilgi. (b) Lateral Accretion Element (LAE) in relation to DAE and LSE within facies association C (pen length $14 \mathrm{~cm}$ ). (c) Laminated Sand Sheet Element (LSE, granule-rich) on top of a facies $C_{1}$ (pen length $13 \mathrm{~cm}$ ) deposit. (d) Convex-up body of a sediment gravity-flow element of flash-flood origin, encased within facies association $\mathrm{C}$ at Bilgi. Hammer for scale, encircled. (e) Overturned cross-strata in type I fluvial package. 
Unsteadiness of water flow, possibly to a lesser extent, is also reflected in the distinctly scoured bases of the type II packages, stacked vertically one on top of the other. Scalloped bases of large-scale foresets also depict directional variability of the flow driving the bars in the downstream direction ([Rubin, 1987] and [Sarkar et al., 1999]). The bar-attached lateral accretion element further indicates existence of a secondary flow component that possibly gained importance in sediment transport with dwindling of the along-channel component. Local incorporation of sediment gravity-flow elements and pebble-bearing sandy bedform elements also subscribes to flow variability, albeit at a larger scale and over longer intervals. Local preservation of aeolian features, like adhesion laminae and translatent strata on bar flanks, within packages of type II further supports a considerable amount of water depth fluctuation within the channels.

Downstream accretion elements and small channel elements both commonly rest on the type II package boundaries, transiting laterally one to the other. The laminated sand-sheet element, on the other hand, generally underlies the package boundaries and overlies the downstream accretion as well as the lateral accretion elements. All three of these elements are bar-related, but separate status for each of them is supported by their different geometries and manifestation of different flow conditions and stages. The bars represented by the downstream accretion element, passing laterally into small channel elements or the lateral accretion elements were thus apparently mid-channel bars, and depict a braided pattern of the river (cf., Holbrook et al., 2006). The inter-relationship between the bar-related elements and small channel elements is onlapping and downlapping. The latter being more common, small channel elements are generally thinner than the downstream or lateral accretion elements, laterally adjacent to or overlying them. Locally occurring sediment gravity flow and sandy bedform elements, generally resting on the package boundaries and overlain by small channel elements, probably formed when vigorous flash floods extended to the relatively distal depositional palaeogeography of the facies association C (Fig. 8d). Every package of type II, bounded below and above by undulated master erosion surfaces, likely represents individual wide channel-belts aggraded one above the other (Holbrook, 2001). The channels were probably semiperennial, never becoming completely dry, although occurrence of minor 
aeolian features immediately under the package boundaries indicates emergence of bartops above the water surface. This contention vindicates the idea of Tirsgaard and Øxnevad (1998) that preservation of aeolian imprints within river channel deposits is best ensured if the river channels are semiperennial in nature. Lack of basal scours and absence of scallop-based foresets, in package III, constituted by a set of downstream accretion elements, laminated sand-sheet elements and small channel elements, in contrast, testify to a nearly stable flow character. Planar laminae and small scours at bartops indicate only a limited scale of flow unsteadiness at the end of the channel-filling process. The limited variation in grain-size between various elements constituting package III also corroborates this contention. The channels in this case thus appear to be perennial. Considering all aspects, the river channels appear to have been shallower and wider with respect to those represented in package II, the velocity of the flow declining consequently.

Type IV packages characterize facies $\mathrm{E}$ and reflect a coupling of a relatively coarser fluvial sandstone unit, followed upward by a finer and distinctly better sorted marine or lacustrine sandstone unit, representing transgression of the standing body of water. The contact between the two components (coarser and finer) is often demarcated by a granular wave winnowed lag in subfacies $\mathrm{E}_{\mathrm{B}}$. Depletion in thickness of the finer component up the facies E packages speaks for overall transgression with a fluctuating rate. The small scale cross-strata within the fluvial units are possibly minor erosional remnants of mid-channel bars with small channels between them. The channels, at the sea or lake margin, had possibly been mostly perennial.

Despite the palaeogeography-related variation in architectural element packaging pattern, the fluvial channels were apparently universally braided. The complete absence of floodplain deposits and the location-specific consistent channel-flow direction further corroborate this contention (cf., [Cant, 1978] and [Cant and Walker, 1978]). This braiding of rivers, notwithstanding other significant differences in their nature, is perfectly consistent with the Precambrian depositional setting (e.g., Long, 2004). 


\section{Discussion}

\subsection{Basin-margin configuration}

The Bagalkot basin-margin is interpreted to have been steep at all three of the locations where the Salgundi Conglomerate is exposed along with the pebbly and granular basal part of the Saundatti Quartzite. The margin is inferred to have been steepest at Ramthal at the easternmost end of the studied stretch; the base-of-slope clastic sedimentary rocks are coarsest there out of the three study locations, and accumulated dominantly through freefall processes. The vertical stack of scree deposits points to frequent tectonic activity, repeatedly creating slopes steeper than the angle-of-repose. Although deposits of such superproximal scree cone affinity are absent at the other two Ramthal sections, viz. the medial and distal sections, the rapid downslope transition of the scree cone deposits to inferred fluvial package III deposits on the plains, with short intervention of package I and negligible occurrence of package II deposits, makes the steepness of the basinmargin apparent.

At the Salgundi measured sections, in contrast, conglomerate dominantly of mass-flow origin gives way downslope to a huge stretch of package I, omitting package II and III deposits completely. It is apparent that the network of rapidly avulsing streamlets debouched directly into the standing body of water. Their channel deposits at Salgundi clearly maintain their high-slope character even at the distal end of the inferred fan, but no sharp slope break was discerned, as had been evident at Ramthal. Dominance of massflow and traction current deposits, however, indicates a depositional slope generally below that of the angle-of-repose. The occurrence of scree deposits, although rare, well above the base of the succession, however, indicates occasional uplift of basement blocks. Nonetheless, tectonic activity was not apparently as frequent as it had been at Ramthal and the palaeoslope was, more or less, constant.

At the Bilgi field site, where only the distal fringe of an inferred fan is present, package I is poorly developed, but scour-based wide channel belts of package II affinity drained the site. Conglomerate, mostly restricted to the base of the studied section, represents a dominantly traction deposit. The surface of the Bilgi fan, at least at its distal part, with 
thinner and still wider channel belts, thus appears to have been even gentler than that of the Salgundi fan and there is no evidence of syndepositional tectonism. Away from Ramthal and towards Bilgi, intensity of tectonic activity became reduced.

\subsection{Bedrock composition vs. tectonic control}

Analysis of successive measured sections down the slope of the preserved alluvial sedimentary cones emphasizes spatial rather than temporal variation, except at Bilgi. Altogether, the seven individual sections studied herein amply illustrate lateral changes in the nature and organization of sediment during the earliest development phase of the Ramdurg Formation, both in dip-parallel and normal directions. Little change in palaeoclimate along the Bagalkot basin margin is expected along the studied stretch, which is only $47 \mathrm{~km}$ long. Prominent Fe-oxide coating as found on top of facies B channels, is present also on most of the contact surfaces between vertically stacked fluvial channel belt deposits in packages II and III, irrespective of palaeogeographic variability implied between them, and this suggests no significant change in the semi-arid climate conducive for mass-flow dominated coarse clastic alluvial fans, either in time, or the space encompassed by the studied stratigraphic segment. In this inferred uniform palaeoclimatic background, bedrock composition could have assumed an enhanced role in determining basin-margin slope and the nature of deposits upon it. Bedrock composition does, indeed, change along the studied stretch significantly. A metasedimentary source contributed dominantly in the southeastern sector, at Ramthal; and the granitic basement contributed most sediment to the westernmost sector, Bilgi; both the sources made comparable contributions at Salgundi, roughly in the middle (Fig. 1a).

Hooke and Le (1967), Bull (1972) and Blair and McPherson (1994) have discussed the potential importance of bedrock for fan deposition, while Blair (1999) and Nichols and Thompson (2005) have demonstrated clearly that bedrock composition does influence basin-margin deposition. Along the margin of the Bagalkot basin, as indicated earlier, the steepest slope was generated in association with the metasedimentary basement, while the crystalline basement gave rise to relatively gentler slopes. This scenario is not likely to 
arise where bedrock composition held the commanding role. The closely jointed and well-laminated metasedimentary source that delivered the blocky or rectangular clasts of the scree facies at Ramthal should have been more rapidly weathered than the crystalline source at Bilgi. The basin-margin at Ramthal should have been gentler in that case and the concomitant lower bed load: suspension load ratio in the sediment budget should have encouraged more sediment gravity-flow deposits (cf. Nichols and Thompson, 2005). Contrary to this expectation sediment gravity-flow products are relatively subordinate in occurrence at Ramthal. It thus seems plausible that the basin-margin was held at a steeper slope than the angle-of-repose for a considerable period of time as a direct consequence of syndepositional tectonics and, in turn, this affected the nature of the coarse immature sediment at the base of the Bagalkot Group. From this point of view, between the three studied locations, Ramthal was presumably tectonically most active. Like scree deposits at different stratigraphic levels, overturned cross-bedding in the fluvial deposits, formed apparently both on hill slopes (package I) and on plains (package III), also corroborates tectonic disturbance, though not unequivocally (cf., Allen and Narayan, 1964). The inferred scree facies has been encountered at Salgundi also, albeit rarely, but not at all at Bilgi.

\subsection{Control on flow duration}

Flow duration in an alluvial channel depends on sustainability of water source and position of channel with respect to the water table. Rates of snow-melting and rainfall, in general, determine the sustainability of the source, climate being the ultimate arbitrator. On the other hand, tectonics, primarily designing the topography, combines with climate to control the position of the water table, except where sea level fluctuation also plays an important role. The apparent variation in river-flow durability in the basinward direction at the Bagalkot basin-margin was probably controlled mainly by seasonal water table fluctuation, accentuated substantially in a semi-arid climate, which was generally dry, but with heavy seasonal rainfall and in complete absence of vegetated soil that holds water. The observed association with sieve conglomerates evinces water percolating down rapidly from channels in package I at the fan apex, the more rapidly incising channels consuming most of the water, leaving the shallower ones high and dry. The infiltrated 
water understandably re-emerged at the 'intersection' level. Low water discharge close to the 'intersection' level because of low hydrographic pressure in connivance with semiarid climate also encouraged the ephemeral nature of the package I channels. Enhanced hydrographic pressure in a downslope direction ensured increasing sustainability of flow, semiperennial for package II and perennial for package III channels. Sustainability of flow down a hill slope and adjacent plains commonly changes with position of the channels with respect to the 'intersection' level, without any major change in climate. In the basal Ramdurg deposits, the semi-arid climate and complete absence of vegetated soil presumably accentuated the effect.

Package thickness variation between types II and III indicates downslope shallowing and perhaps also broadening of the channels of the Ramdurg rivers. The flows turned increasingly steady and weaker with loss of slope gradient. The inferred rapid change in gradient across the scree cone margin can be held responsible for omission of the fluvial package II at Ramthal. On the other hand, poor development of package I at Bilgi is attributable to the relatively low overall slope gradient. One can assume a gradient less than that of the Ramthal scree cone and more than that of the Bilgi fan for the fan-delta interpreted at Salgundi, where package I was deposited in substantial quantities, with complete absence of packages II and III. This assumption is consistent with the previous observation that tectonic activity was most intense at Ramthal and declined progressively away from there. The basin-margin was closest to the standing body of water where it was steepest, and farthest removed where it was at its most gentle (Fig. 9). In accordance with this suggestion, the transitional facies, E, is altogether absent at Ramthal and achieved its maximum preserved thickness at Bilgi (compare Fig. 5, Fig. 6 and Fig. 7). Tectonics thus appears to have been the prime factor in determining palaeogeomorphology and fluvial facies characteristics along the studied stretch of the Bagalkot basin-margin. 


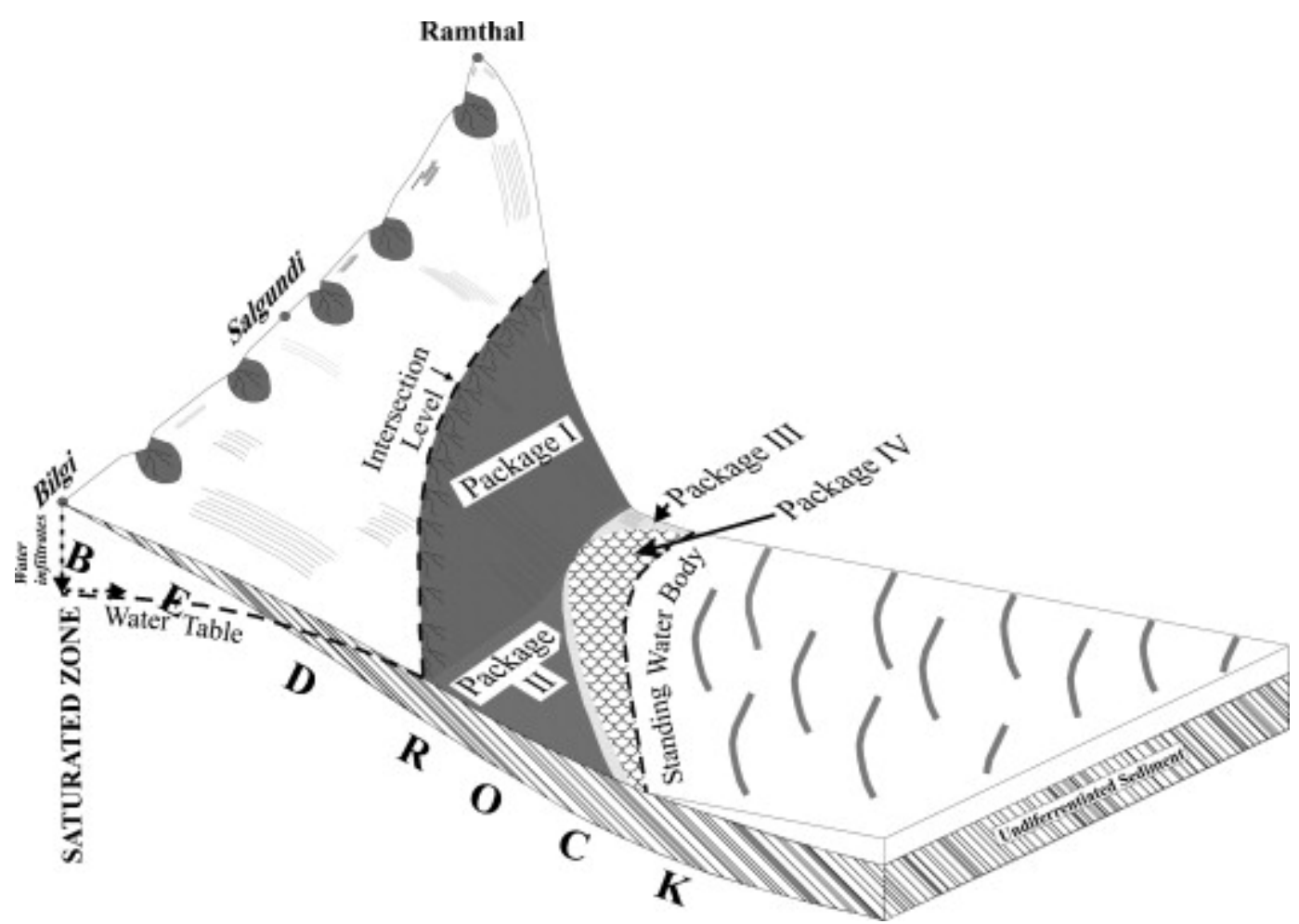

Fig. 9. Cartoon depicting spatial distribution of fluvial packages Type I, II and III, shown only in reference to the water table and postulating slope control on distance of the standing water body from the basin-margin.

\subsection{Base profile change}

The Ramdurg Formation, as a whole, is fining-upward having coarser clastics at its base and argillites at the top; the latter, with carbonate rocks, constitute the next younger Formation, Yargatti, entirely. Its studied basal segment is interrupted near the top by a granular lag, upon which rests the non-repetitive facies $\mathrm{E}$ that is again upward-fining within itself, gradually losing fluvial deposits. Facies $\mathrm{E}$ is, therefore, a part of a transgressive systems tract (TST) that continues further upward. The stratigraphic segment underlying the lag and resting on an unconformity is interpreted as a lowstand systems tract (LST) (Fig. 1b). Progradation in the LST is most pronounced in the Salgundi Conglomerate Member in the proximal section at the Salgundi field location (Fig. 6a). The fluvial succession of the Saundatti Quartzite, overlying the Salgundi Conglomerate, suggests channel aggradation, presumably as a result of slow rise of river base profile (cf., Blum and Tornqvist, 2000). Its fining-upward trend and onlapping of 
distal facies on proximal facies is attributable to loss of slope gradient through the aggradation (cf., Catuneanu, 2006).

As the standing body of water transgressed, it eventually drowned the alluvial sedimentary cones. This passage appears to have been most rapid at Ramthal, as evinced by the total absence of the transitional facies E. At Salgundi, the transitional facies is present, but only in the form of subfacies $E_{B}$. In contrast, at Bilgi, subfacies $E_{D}$ substitutes for the former subfacies, rendering the slowest transgressive transition. This observation may at first appear antithetic to the perception that transgressions and regressions should be more rapid on gentler slopes, but actually reflects the better development of transgressive-regressive tongues on a slope in response to fluctuating rates of overall transgression before the final drowning of the basin-margin. Apparently, tectonically-induced basin-margin slope gradient was the dominant control on the nature of the fluvial-marine/lacustrine transition in the study area as well.

\section{Conclusions}

A scree cone, a fan-delta and an alluvial fan characterised the eastern sector of the Mesoproterozoic Bagalkot basin-margin, India. In a semi-arid climate, the rivers evolved from ephemeral to perennial, through semi-perennial, down the basin-margin slope. Wide seasonal fluctuation of the water table under a semi-arid climate and complete absence of vegetated soil was mainly responsible for this change in flow durability. Irrespective of the wide variability in flow duration within them, the channels always had a braided pattern, as can be predicted for Precambrian alluvial systems in general.

The basal segment of the Ramdurg Formation under focus here, is a product of base-level lowstand. In consequence, the proximal fan is profoundly progradational, though the distal fluvial succession is aggradational owing to progressive loss of the depositional slope gradient. A standing body of water subsequently transgressed upon the fan complex. Short-scale transgressions and regressions at the transition between the basal lowstand and the younger transgressive systems tract are best recorded where the tectonics-induced slope was comparatively gentle, being farthest from the most active 
part of the basin margin. Tectonics-related basin-margin gradient played the commanding role in determining the depositional strike- and dip-parallel variations in mode of sediment transport and deposition, drainage pattern and sequence architecture, especially fluvial, against the backdrop of a rise in base-profile, which was initially slow, but became enhanced later.

\section{References}

Allen and Narayan, 1964 J.R.L. Allen and J. Narayan, Cross-stratified units, some with silt bands, in the Folkestone Beds (Lower Greensand) of southeast England, Geolgie en Mijnbouw 43 (1964), pp. 451-461.

Blair, 1999 T.C. Blair, Cause of dominance by sheetflood vs. debris-flow processes on two adjoining fans, Death Valley, California, Sedimentology 46 (1999), pp. 1015-1028.

Blair and McPherson, 1994 T.C. Blair and J.G. McPherson, Alluvial fans and their natural distinction from rivers based on morphology, hydraulic processes, sedimentary processes, and facies assemblages, J. Sediment. Res. A 64 (1994), pp. 450-489.

Blum and Tornqvist, 2000 M. Blum and T. Tornqvist, Fluvial responses to climate and sea-level change: a review and forward, Sedimentology 47 (2000), pp. 2-48.

Bose and Sarkar, 1991 P.K. Bose and S. Sarkar, Basinal autoclastic massflow regime in Precambrian Chanda Limestone Formation, Adilabad, India, Sediment. Geol. 73 (1991), pp. 299-315.

Buck and Minter, 1985 S.G. Buck and W.E.L. Minter, Placer formation by fluvial degradation of an alluvial fan sequence: the Proterozoic Carbon Leader placer, Witwatersrand Supergroup, South Africa, J. Geol. Soc. Lond. 142 (1985), pp. 757-764. 
Bull, 1972 Bull, W.B., 1972. Recognition of alluvial fan deposits in the stratigraphic record. In: Rigby, J.K., Hamblin, W.K. (Eds.), Recognition of ancient sedimentary environments. Soc. Eco. Paleo. Mineral. Special Publ. 16, pp. 63-83.

Campbell, 1989 C.S. Campbell, Self-lubrication for long runout landslides, J. Geol. 97 (1989), pp. 63-665.

Campbell et al., 1995 C.S. Campbell, P.W. Cleary and M. Hopkins, Large-scale landslide simulations: Global deformation, velocities and basal friction, J. Geophys. Res. 100 (1995), pp. 8267-8283.

Cant, 1978 Cant, D.J., 1978. Development of a facies model for sandy braided river sedimentation: Comparison of the South Saskatchewan River and the Battery Point Formation. In: Miall, A.D. (Ed.), Fluvial Sedimentology. Can. Soc. Petrol. Geologists, Calgary, pp. 627-639.

Cant and Walker, 1978 D.J. Cant and R.G. Walker, Fluvial process and facies sequences in the sandy braided South Saskatchewan River, Sedimentology 26 (1978), pp. 625-648.

Catuneanu, 2006 O. Catuneanu, Principles of Sequence Stratigraphy, Elsevier, Amsterdam (2006) p. 375.

Clifton, 1973 H.E. Clifton, Pebble segregation and bed lenticularity in wave worked versus alluvial gravel, Sedimentology 20 (1973), pp. 173-183.

Cotter, 1978 Cotter, E., 1978. The evolution of fluvial style, with special reference to the central Appalachian Palaeozoic. In: Miall, A.D. (Ed.), Fluvial Sedimentology. Can. Soc. Pet. Geol. Mem. 5, pp. 361-384. 
Davis et al., 2002 A.M. Davis, J.C. Aitchison, Badengzhu, H. Luo and S. Zyabrev, Paleogene island arc collision-related conglomerates, Yarlung-Tsangpo suture zone, Tibet, Sediment. Geol. 150 (2002), pp. 247-273.

Donaldson and de Kemp, 1998 J.A. Donaldson and E.A. de Kemp, Archean quartz arenites in the Canadian Shield: examples from the Superior and Churchill Provinces, Sediment. Geol. 120 (1998), pp. 153-176.

Els, 1998 B.G. Els, The question of alluvial fans in the auriferous Archean and Proterozoic successions of South Africa, S. Afr. J. Geol. 101 (1998), pp. 17-25

Enos, 1977 P. Enos, Flow regimes in debris flow, Sedimentology 24 (1977), pp. 133-142.

Eriksson et al., 2006 P.G. Eriksson, A.J. Bumby, J.J. Brümer and M. van der Neut, Precambrian fluvial deposits: enigmatic palaeohydrological data from the c. 2-1.9 Ga Waterberg group, South Africa, Sediment. Geol. 190 (2006), pp. 25-46.

Fisher, 1971 R.V. Fisher, Features of coarse-grained, high concentration fluids and their deposits, J. Sediment. Petrol. 41 (1971), pp. 916-927.

Friend, 1978 Friend, P.F., 1978. Distinctive features of some ancient river systems. In: Miall, A.D. (Ed.), Fluvial Sedimentology. Can. Soc. Pet. Geol. Mem. 5, pp. 531-543.

Frostick and Reid, 1989 L.E. Frostick and I. Reid, Climate versus tectonic controls of the fan sequences: lessons from the dead sea, Isr. J. Geol. Soc. 146 (1989), pp. 527-538.

Fuller, 1985 A.O. Fuller, A contribution to the conceptual modeling of pre-Devonian fluvial systems, Trans. Geol. Soc. S. Afr. 88 (1985), pp. 189-194. 
Gani, 2004 M.R. Gani, From turbid to lucid: a straightforward approach to sediment gravity flows and their deposits, Sediment. Rec. 2 (3) (2004), pp. 4-8.

Garuraja, 1983 Garuraja, M.N., 1983. Preliminary report on the stromatolites and microbiota from rock formation of Kaladgi basin, Karnataka, Geol. Surv. India, unpublished report.

Hein, 1982 F.J. Hein, Depositional mechanism of deep-sea coarse clastic sediments, Cap Enruge Formation, Quebec. Can. J. Earth Sci. 19 (1982), pp. 267-287.

Heward, 1978 Heward, A.P., 1978. Alluvial fan sequence and megasequence models: with examples from Westphalian D - Stephanian B coalfields, northern Spain. In: Miall, A.D. (Ed.), Fluvial Sedimentology. Can. Soc. Pet. Geol. Mem. 5, pp. 669-702.

Holbrook, $2001 \mathrm{~J}$. Holbrook, Origin, genetic interrelationships, and stratigraphy over the continuum of fluvial channel-form bounding surfaces: an illustration from middle Cretaceous strata, southeastern Colorado, Sediment. Geol. 144 (2001), pp. 179-222.

Holbrook et al., 2006 J. Holbrook, R.W. Scott and F.E. Odoh-Ikuenobe, Base-level buffers and buttresses: a model for upstream versus downstream control on fluvial geometry and architecture within sequences, J. Sediment. Geol. 76 (2006), pp. 162-174.

Hooke and Le, 1967 R. Hooke and B. Le, Processes on arid-region alluvial fans, J. Geol. 75 (1967), pp. 438-460.

Jayaram et al., 1983 Jayaram, S., Venkatasubramaniam, V.S., Radhakrishna, B.P., 1983. Geochronology and trace element distribution in some tonalitic and granitic gneisses of the Dharwar craton, Precambrian of south India. In: Naqvi, S.M., Rogers, J.J.W. (Eds.), Proceedings of the Indo-US Workshop, Hyderabad. Mem. Geol. Soc. India. 8, 377-389. 
Jayaprakash et al., 1987 Jayaprakash, A.V., Sundaram, V., Hans, K., Mishra, R.N., 1987. Geology of the Kaladgi-Badami Basin, Karnataka. In: Purana Basins of Peninsular India (middle to late Proterozoic), Mem. Geol. Soc. India. 6, 201-225.

Kale, 1991 V.S. Kale, Constraints on the evolution of the Purana Basins of Peninsular India, J. Geol. Soc. India 38 (3) (1991), pp. 231-252.

Kale et al., 1996 V.S. Kale, V. Ghunakikar, P.P. Thomas and V.V. Peshwa, Macrofacies architecture of the first transgressive suite along the southern margin of the Kaladgi Basin, J. Geol. Soc. India 48 (1996), pp. 75-92.

Kirk, 1983 M. Kirk, Bar development in a fluvial sandstone (West-phalian 'A'), Scotland, Sedimentology 30 (1983), pp. 727-742.

Levell, 1980 B.K. Levell, A late Precambrian tidal shelf deposit, the Lower Sandford Formation, Finnmark, North Norway, Sedimentology 27 (1980), pp. 539-557.

Long, 1978 Long, D.G.F., 1978. Proterozoic stream deposits: some problems of recognition and interpretation of ancient fluvial systems In: Miall, A.D. (Ed.), Fluvial Sedimentology. Can. Soc. Pet. Geol. Mem. 5, pp. 313-341.

Long, 2004 D.G.F. Long, Precambrian Rivers. In: P.G. Eriksson, W. Altermann, D.R. Nelson, W.U. Mueller and O. Catuneanu, Editors, The Precambrian Earth: Tempos and Events, Elsevier, Amsterdam (2004), pp. 660-663.

Lowe, 1976 D.R. Lowe, Grain flow and grain flow deposits, J. Sediment. Petrol. 46 (1976), pp. 188-190.

Mack and Rasmussen, 1984 G.H. Mack and K.A. Rasmussen, Alluvial-fan sedimentation of the Cutler Formation (Permo-Pennsylvanian) near Gateway, Colorado. Geol. Soc. Am. Bull. 95 (1984), pp. 109-116. 
Massari and Colella, 1988 F. Massari and A. Colella, Evolution and types of fan-delta systems in some major tectonic settings. In: W. Nemec and R.J. Steel, Editors, Fan Deltas: Sedimentology and Tectonic Settings, Blackie, London (1988), pp. 103-122.

Miall, 1996 A.D. Miall, The Geology of Fluvial Deposits: Sedimentary Facies, Basin Analysis and Petroleum Geology, Springer, New York (1996) p. 582.

Middleton and Hampton, 1976 G.V. Middleton and M.A. Hampton, Subaquous sediment transport and deposition by sediment gravity flows. In: D.J. Stanley and D.J.P. Swift, Editors, Marine sediments, transport and environmental management, John Wiley, New York (1976), pp. 197-219.

Mulder and Alexander, 2001 T. Mulder and J. Alexander, The physical character of subaqueous sedimentary density flows and their deposits, Sedimentology 48 (2001), pp. 269-299.

Nemec and Postma, 1993 Nemec, W., Postma, G., 1993. Quarternary alluvial fans in southwestern Crete: sedimentation processes and geomorphic evolution. In: Marzo, M., Puigdefabregas, C. (Eds.). Alluvial sedimentation, Int. Assoc. Sediment. Special Publ. 17, 235-276.

Nemec and Steel, 1984 Nemec, W., Steel, R.J., 1984. Alluvial and coastal conglomerates: their significant features and some comments on gravelly mass-flow deposits. In: Koster, E.H., Steel, R.J. (Eds.), Sedimentology of Gravels and Conglomerates. Can. Soc. Pet. Geol. Mem. 10, pp. 1-31.

Nichols and Thompson, 2005 G. Nichols and B. Thompson, Bedrock lithology control on contemporaneous alluvial fan facies, Oligo-Miocene, southern Pyrenees, Spain, Sedimentology 52 (2005), pp. 571-585. 
Nilsen, 1985 In: T.H. Nilsen, Editor, Modern and ancient alluvial fan deposits. Benchmark Papers in Geology 87, Van Nostrand Reinhold, New York (1985).

Olsen, 1989 H. Olsen, Sandstone-body structures and ephemeral stream processes in the Dinosaur Canyon Member, Moenave Formation (Lower Jurassic), Utah, U.S.A., Sediment. Geol. 61 (1989), pp. 207-221.

Peakall et al., 2001 J. Peakall, M. Felix, B. McCaffrey and B. Kneller, Particulate gravity currents: perspectives. In: W. McCaffrey, B. Kneller and J. Peakall, Editors, Particulate Gravity Currents, IAS Special Publ. (2001), p. 31.

Peshwa et al., 1989 Peshwa, V.V., Phadke, A.V., Phansalkar, V.G., Soman, G.R., Deolankar, S.B., 1989. Geology of the Kaladgi Basin and associated rocks in parts of northern Karnataka and Western Maharashtra: A study based on Remote Sensing Techniques. Unpublished ISRO-RESPOND Project Report; Geology Department, Poona University. 118+18pl.

Pfluger and Seilacher, 1991 F. Pfluger and A. Seilacher, Flash flood conglomerates. In: G. Einsele, W. Ricken and A. Seilacher, Editors, Cycles and Events in Stratigraphy, Springer-Verlag, Berlin, New York (1991), pp. 383-391.

Postma, 1990 G. Postma, Depositional architecture and facies of river and fan deltas: a synthesis. In: A. Colella and D.B. Prior, Editors, Coarse-Grained Deltas 10, IAS Special Publ., Blackwell, Oxford (1990), pp. 13-27.

Radhakrishna and Vaidyanathan, 1994 B.P. Radhakrishna and R. Vaidyanathan, Geology of Karnataka, Geological Society of India, Bangalore (1994) p. 298.

Raha and Sastry, 1982 P.K. Raha and M.V.A. Sastry, Stromatolites and Precambrian Stratigraphy in India, Precambrian Res. 18 (1982), pp. 293-318. 
Rahn, 1967 P.H. Rahn, Sheetfloods, streamfloods and the formation of pediments, Ann. Assoc. Am. Geogr. 57 (1967), pp. 593-604.

Rao et al., 1999 V.V.S. Rao, B. Sreenivas, V. Balaram, P.K. Govil and R. Srinivasan, The nature of the Archean upper crust as revealed by the geochemistry of the Proterozoic shales of the Kaladgi basin, Karnataka, southern India, Precambrian Res. 98 (1999), pp. 53-65.

Rubin, 1987 D.M. Rubin, Cross-beddings, bedforms an paleocurrents: Concepts in Sedimentology and Paleontology 1, Soc. Econ. Paleontol. Mineral. (1987), p. 187.

Rust and Koster, 1984 B.R. Rust and E.H. Koster, Coarse alluvial deposits. In: R.G. Walker, Editor, Facies Models (second ed.), Geological Association of Canada, Toronto (1984), pp. 53-69.

Sarkar et al., 1999 S. Sarkar, R. Mazumder and P.K. Bose, Changed bedform dynamics: some observations from Proterozoic Chaibasa formation, India, J. Indian Assoc. Sediment. 18 (1999), pp. 31-40.

Schultz, 1984 A.W. Schultz, Subaerial debris flow deposition in the upper Paleozoic Cutler Formation, western Colorado, J. Sediment. Petrol. 54 (1984), pp. 759-772.

Selley, 1965 R.C. Selley, Diagnostic characters of fluviatile sediments of the Torridonian formation (Precambrian) of northwest Scotland, J. Sediment. Res. 35 (1965), pp. 366380.

Shanmugam, 2000 G. Shanmugam, 50 years of turbidite paradigm (1950-1990s): deepwater processes and facies models - a critical perspective, Mar. Petrol. Geol. 17 (2000), pp. 285-342 
Talbot and Williams, 1979 M.R. Talbot and M.A.J. Williams, Cyclic alluvial fan sedimentation on the flanks of fixed dunes, Janjari, central Niger, Catena 6 (1979), pp. 43-62.

Tirsgaard and Øxnevad, 1998 H. Tirsgaard and I.E.I. Øxnevad, Preservation of prevegetational mixed fluvio-aeolian deposits in a humid climatic setting: an example from the Middle Proterozoic Eriksfjord Formation, Southwest Greenland, Sediment. Geol. 120 (1-4) (1998), pp. 295-317.

Todd, 1989 S.P. Todd, Sream-driven, high-density gravelly traction carpets: possible deposits in the Trabeg Conglomerate Formation, SW Ireland and some theoretical considerations of their origin, Sedimentology 36 (1989), pp. 513-530.

Viswanathaiah and Gowda, 1975 M.N. Viswanathaiah and M.J.C. Gowda, Algal stromatolite in high calcium limestones from Kaladgi group (Pre-Cambrian), near Kuligod, Belgaum district, Karnataka, Proc. 4th Colloq. Ind. Micropalae. Strat. O.N.G.C. Dehradun (1975), pp. 201-206.

Viswanathaiah, 1977 M.N. Viswanathaiah, Lithostratigraphy of the Kaladgi and Badami groups, Karnataka, Ind. Mineralogist 18 (1977), pp. 122-132.

Wescott and Ethridge, 1990 W.A. Wescott and F.G. Ethridge, Fan deltas - alluvial fans in coastal settings. In: A.H. Rachocki and M. Church, Editors, Alluvial Fans: a Field Approach, Wiley, Chichester (1990), pp. 195-211.

Walker, 1984 R.G. Walker, Turbidites and associated coarse clastic deposits. In: R.G. Walker, Editor, Facies Models (second ed.), Geological Association of Canada, Toronto (1984), pp. 171-188.

Corresponding author. Fax.: +913324146781. 